\title{
Engineered type six secretion systems deliver active exogenous effectors and
}

\section{Cre recombinase}

Steven J. Hersch ${ }^{1}$, Linh Lam ${ }^{1}$, Tao G. Dong ${ }^{1,2}$

\section{Affiliations:}

${ }^{1}$ Department of Ecosystem and Public Health, University of Calgary, 3330 Hospital Dr. NW, Calgary, AB, Canada, T2N4N1

${ }^{2}$ State Key Laboratory of Microbial Metabolism, Joint International Research Laboratory of Metabolic \& Developmental Sciences, School of Life Sciences and Biotechnology, Shanghai Jiao Tong University, Shanghai, 200240, China

Correspondence to tdong@ucalgary.ca

Running title: Engineering the T6SS

Keywords: Type six secretion system, protein secretion, genetic editing, Cre recombinase, interspecies interactions, effector, antimicrobial

Subject Categories: Recombinant protein delivery, microbe-microbe interactions 
bioRxiv preprint doi: https://doi.org/10.1101/2021.05.11.443660; this version posted May 11, 2021. The copyright holder for this preprint (which

was not certified by peer review) is the author/funder, who has granted bioRxiv a license to display the preprint in perpetuity. It is made available under aCC-BY-NC-ND 4.0 International license.

Hersch et al.

Engineering the T6SS

1

2

3

4

5

6

\section{$\underline{\text { Abstract }}$}

Genetic editing has revolutionized biotechnology but delivery of endonuclease genes as DNA can lead to aberrant integration or overexpression, leading to off-target effects. Here we develop a mechanism to deliver Cre recombinase as a protein by engineering the bacterial type six secretion system (T6SS). Using multiple T6SS fusion proteins, Aeromonas dhakensis or attenuated Vibrio cholerae donor strains, and a gain-of-function cassette for detecting Cre recombination, we demonstrate successful delivery of active Cre directly into recipient cells. Most efficient transfer was achieved using a truncated version of PAAR2 from V. cholerae, resulting in a relatively small (118 amino acid) 'delivery tag'. We further demonstrate the versatility of this system by delivering an exogenous effector, TseC, enabling $V$. cholerae to kill Pseudomonas aeruginosa. This implicates that $P$. aeruginosa is naturally resistant to all native effectors of $V$. cholerae and that the TseC chaperone protein is not required for its activity. Moreover, it demonstrates that the engineered system can improve T6SS efficacy against specific pathogens, proposing future application in microbiome manipulation or as a next-generation antimicrobial. Inexpensive and easy to produce, this protein delivery system has many potential applications ranging from studying T6SS effectors to genetic editing.

\section{Importance}

Delivery of protein-based drugs, antigens, and gene-editing agents has broad applications. The type VI protein secretion system (T6SS) can target both bacteria and eukaryotic cells and deliver proteins of diverse size and function. Here we harness the T6SS to successfully deliver Cre recombinase to genetically edit bacteria without requiring the introduction of exogenous DNA into the recipient cells. This demonstrates a promising advantage over current genetic editing tools that require transformation or conjugation of DNA. The engineered secretion tag can also deliver a heterologous antimicrobial toxin that kills an otherwise unsusceptible pathogen, Pseudomonas aeruginosa. These results demonstrate 
bioRxiv preprint doi: https://doi.org/10.1101/2021.05.11.443660; this version posted May 11, 2021. The copyright holder for this preprint (which

was not certified by peer review) is the author/funder, who has granted bioRxiv a license to display the preprint in perpetuity. It is made available under aCC-BY-NC-ND 4.0 International license.

Hersch et al.

Engineering the T6SS

the potential of T6SS-mediated delivery in areas including genome editing, killing drug-resistant pathogens, and studying toxin functions.

\section{$\underline{\text { Introduction }}$}

Genetic editing tools have provided incredible resources for DNA manipulation. In addition to

DNA encoding the active enzyme, which can potentially cause unwanted mutations by integrating into

37 potentially alleviate these issues by eliminating the possibility of DNA integration while simultaneously allowing for more control over enzyme dosage. secretion systems (T4SS), which are often virulence factors that pass unfolded effector proteins through

41 a central pore into eukaryotic host cells(6). Several successful endeavors have demonstrated that these

42 secretion systems can be harnessed for delivery of recombinant proteins(7, 8). Another, more recently

43 discovered system, is the type six secretion system $(\mathrm{TGSS})(9,10)$. The T6SS resembles a molecular spear

44 gun and uses physical puncturing to penetrate nearby bacteria or eukaryotic cells in order to deliver

45 protein effectors with various destructive activities $(11,12)$. Importantly, the toxicity of the system

46 towards prey cells is primarily driven by the effectors since the damage caused by the puncture itself

47 appears negligible, as demonstrated by effectorless strains constructed in multiple species(13-17). 
bioRxiv preprint doi: https://doi.org/10.1101/2021.05.11.443660; this version posted May 11, 2021. The copyright holder for this preprint (which

was not certified by peer review) is the author/funder, who has granted bioRxiv a license to display the preprint in perpetuity. It is made available under aCC-BY-NC-ND 4.0 International license.

Hersch et al.

Engineering the T6SS

Rather than passing unfolded proteins through a pore like the T3SS and T4SS, the T6SS mounts

effectors onto the spear structure, which permits folding prior to delivery. Effectors can be loaded in the

long Hcp protein tube that is thrust forward, or mounted on a pointed spear-head comprised of a trimer

51 of VgrG proteins and a sharp PAAR protein tip. Notably, effectors can be non-covalently attached for

52 delivery ('cargo' effectors) or included as extended domains of the structural proteins, which are termed

53 'evolved' or 'specialized' effectors. Past attempts at delivering recombinant proteins using T6SSs have

54 revealed key challenges(18) as well as some successes, which include delivery of $\beta$-lactamase into

55 eukaryotic cells(19-21) and fusion of two exogenous effectors for secretion(21, 22). Vibrio cholerae

56 encodes one of the best characterized T6SS and the T6SS has been particularly well characterized in

57 strain V52, which is a non-pandemic strain with a constitutively active T6SS(9). V. cholerae V52 naturally

employs five known effectors to inhibit macrophage or amoeba that phagocytose it, or to kill

neighbouring bacteria including $\mathrm{T} \mathrm{SS}^{+}$competitors such as Aeromonas dhakensis(23-26). In contrast,

some species, such as Pseudomonas aeruginosa, survive attacks by the $V$. cholerae T6SS, but the

mechanism of this resistance remains uncertain(27). The five T6SS effectors of $V$. cholerae include two 
bioRxiv preprint doi: https://doi.org/10.1101/2021.05.11.443660; this version posted May 11, 2021. The copyright holder for this preprint (which

was not certified by peer review) is the author/funder, who has granted bioRxiv a license to display the preprint in perpetuity. It is made available under aCC-BY-NC-ND 4.0 International license.

Hersch et al.

Engineering the T6SS

72 comparable to the effector domains of VgrG1 and VgG3. 3) Cre instigates efficient and specific DNA

73 recombination allowing for detection in recipient cells. 4) Cre/loxP recombination is commonly used in

74 numerous species and therefore Cre delivery has immediate potential applications. 5) Cre delivery

75 represents a proof-of-principle for transfer of active genetic editing enzymes into the cytoplasm of

76 target cells, which establishes the system for future development using targeted endonucleases such as

77 CRISPR-Cas9.

We develop a relatively small (118 amino acids), yet highly efficient, delivery tag that achieves

79

80

81

82

83

84

85

86

87

88

89

90

91

92

93

94

95

substantial levels of loxP-site recombination in recipients; this highlights its potential for future genetic editing applications. We further demonstrate the utility of the system by efficiently delivering an exogenous T6SS effector that grants $V$. cholerae the ability to kill $P$. aeruginosa, demonstrating the application of the system towards studying effector activity or targeting particular bacterial prey.

\section{$\underline{\text { Results }}$}

\section{Cre fused to VgrG is secreted in a T6SS-dependent manner}

We hypothesized that evolved VgrG proteins would be most amenable to secreting exogenous proteins due to their natural fusion to effector domains. Specifically, by replacing the effector domain with a protein of interest, toxic effector activity is removed while leaving the natural linker to the VgrG domain intact, which may be important for proper folding and loading onto the T6SS tip. Since $V$. cholerae V52 has two evolved VgrGs and one of the best studied T6SSs, we employed it to deliver Cre recombinase cargo in initial T6SS engineering experiments.

To generate VgrG-Cre fusions, we first inserted vgrG genes - truncated prior to their effector domains - into a plasmid vector with a C-terminal 3x V5 tag (Fig. 1A); these effectorless VgrG plasmids served as 'no-Cre' controls. Notably, the remaining linker region of $\mathrm{VgrG1}$ includes a proline-rich region 
bioRxiv preprint doi: https://doi.org/10.1101/2021.05.11.443660; this version posted May 11, 2021. The copyright holder for this preprint (which

was not certified by peer review) is the author/funder, who has granted bioRxiv a license to display the preprint in perpetuity. It is made available under aCC-BY-NC-ND 4.0 International license.

Hersch et al.

Engineering the T6SS

(PRR; codons 686-725) where $35 \%$ of the residues are proline, including six in a row. VgrG3 also has a

97 linker between the effector domain and the VgrG domain; the 'conserved domains analysis feature' of

BLAST(33) revealed that this region could be split into a linker associated with the lysozyme domain

(646-717) and another linker region (540-645). Since it was unclear if these linkers were important for

T6SS-mediated secretion, we introduced Cre recombinase at two different locations: either maintaining

101

the entire linker $\left(\mathrm{VgrG}_{725}-\mathrm{Cre}_{3 \mathrm{~V}}\right.$ and $\left.\mathrm{VgrG3}{ }_{717}-\mathrm{Cre}_{3 \mathrm{~V}}\right)$ or removing the PRR or lysozyme-associated linker

domains (VgrG1 $1_{685}-\mathrm{Cre}_{3 \mathrm{~V} 5}$ and $\operatorname{VgrG} 3_{645}-\mathrm{Cre}_{3 \mathrm{~V} 5}$, respectively)(Fig. 1A).

We electroporated the VgrG-Cre plasmids into the V. cholerae V52 strain and tested secretion

by western blotting for the V5 antigen. Both 'no-Cre' controls were secreted from wild-type bacteria but

release of these truncated $\mathrm{VgrGs}$ since the proteins were fully expressed in the $\Delta$ tss $M$ mutant (whole-

111 than VgrG3-Cre. To test if VgrG1-Cre was secreted at all, we tested its ability to deliver the cargo

112 effector, TseL. Normally TseL binds to VgrG1 for delivery and a V52 vgrG1 mutant does not kill a

113 sensitive strain lacking the TseL immunity gene, $t s i V 1(30,31)$. The $\operatorname{VgrG} 1_{725}-\mathrm{Cre}_{3 \mathrm{~V} 5}$ fusion was able to

114 complement TseL delivery in a $\Delta v \operatorname{vg} G 1$ strain (Fig. S1), suggesting that $\mathrm{VgrG} 1_{725}-\mathrm{Cre}_{3 \mathrm{~V} 5}$ can bind to TseL

115 and be secreted into neighbouring cells. We therefore continued to examine the VgrG1-Cre fusions in

116 further assays. 
bioRxiv preprint doi: https://doi.org/10.1101/2021.05.11.443660; this version posted May 11, 2021. The copyright holder for this preprint (which

was not certified by peer review) is the author/funder, who has granted bioRxiv a license to display the preprint in perpetuity. It is made available under aCC-BY-NC-ND 4.0 International license.

Hersch et al.

Engineering the T6SS

We next sought to determine if the engineered fusions could deliver active Cre recombinase

into neighbouring cells. We constructed a plasmid-based cassette for detecting Cre-mediated

121

recombination in recipient cells: The plasmid contains a floxed (flanked by loxP sites) ampicillin

122

resistance $\left(A m p^{R}\right)$ cassette that interrupts translation of a gentamicin resistance (Gent $\left.{ }^{R}\right)$ gene (Fig. 1C).

We termed this plasmid pFIGR for floxed interruption in gentamicin resistance. Before Cre-

124

recombination, pFIGR grants ampicillin resistance but the cells remain gentamicin sensitive. Upon Cre-

mediated recombination, the block is lifted and the Gent ${ }^{R}$ gene is expressed, granting gentamicin

resistance to the bacteria. This provides a simple method for detecting Cre recombination as growth of

127 recipient cells on media containing gentamicin. Notably, recipients would only become sensitive to

128 ampicillin if all copies of pFIGR (approximately 20 / cell) lost the Amp ${ }^{R}$ cassette.

To avoid killing the recipients with T6SS effectors, we used the same V. cholerae V52

background - encoding all immunity genes - as the recipient. Furthermore, to prevent re-secretion of

131 the fusions by the T6SS of recipient cells, the $\Delta t s s M$ mutant was used as the recipient strain. Finally, for

132 enumeration of total recipients, we also introduced a kanamycin resistant $\left(\operatorname{Kan}^{R}\right)$ plasmid that is

133 compatible with pFIGR.

After combining donor cells and recipients containing pFIGR, we found that all four of the VgrG-

135 Cre fusions led to significant levels of Gent ${ }^{R}$ colony forming units (C.F.U.) (Fig. 1D). The VgrG3 ${ }_{717}-\mathrm{Cre}_{3 v 5}$

136 construct was the most effective, leading to about 500-fold more Gent ${ }^{R}$ C.F.U. than controls.

137 Importantly, we confirmed that the gain of gentamicin resistance required Cre, since controls lacking Cre

138 demonstrated background levels of Gent ${ }^{R}$ C.F.U.. Moreover, three pieces of evidence support that the

139 observed gentamicin resistance was dependent on direct T6SS-mediated delivery: 1) a Cre-only control

140 that lacks a VgrG 'delivery tag' did not increase the number of Gent ${ }^{R}$ colonies. 2) Wild-type donors

141 demonstrated significantly more Cre delivery (Gent ${ }^{R}$ C.F.U.) than T6SS-null ( $\Delta$ tssM) strains (Fig. 1D, S2A).

142 3) Attempts to deliver Cre under conditions that are prohibitive of the T6SS, including in liquid media or 
Hersch et al.

with a barrier separating the donor and recipient cells, failed to increase the yield of Gent ${ }^{R}$ colonies (Fig.

S2B, C). Notably, Cre delivery does not appear to recombine every copy of pFIGR in a cell, since Amp ${ }^{R}$

145 (non-recombined FIGR) and $\operatorname{Kan}^{R}$ (total recipient) C.F.U. counts were indistinguishable - suggesting that

146 some copies of $p F I G R$ retain the $A m p^{R}$ gene (Fig. S2A).

Since the T6SS has been associated with horizontal gene transfer, we also considered that

148 transfer of either pFIGR or the Cre donor plasmid (which is chloramphenicol resistant; $\mathrm{Cm}^{\mathrm{R}}$ ) could result

149 in a strain containing both plasmids - leading to Gent ${ }^{R}$ colonies. However, this did not appear to occur

150 since the Cre-only control plasmid did not increase the numbers of Gent ${ }^{R}$ C.F.U. (Fig. 1D) and not a single

$151 \mathrm{Cm}^{\mathrm{R}} \mathrm{Gent}^{\mathrm{R}}$ double-resistant colony was detected across all replicates (data not shown). These data

152 suggest that the observed Gent ${ }^{R}$ colonies resulted from genuine T6SS-mediated delivery of active Cre

153 protein.

Data from this initial Cre delivery experiment revealed some limitations to be addressed: First,

157 fusions result in undetermined toxicity or may exert a resource strain on donor cells expressing the large 158 recombinant proteins. The second limitation was that we observed reduced recipient survival with wild159 type donors compared to $\Delta t s s M$ (Fig. S2A), suggesting that T6SS effectors were killing recipient cells

160 despite the recipient strains encoding all immunity genes. These limitations are addressed in the 161 following sections.

\section{Using a PAAR2-Cre delivery vector improves donor fitness}


bioRxiv preprint doi: https://doi.org/10.1101/2021.05.11.443660; this version posted May 11, 2021. The copyright holder for this preprint (which

was not certified by peer review) is the author/funder, who has granted bioRxiv a license to display the preprint in perpetuity. It is made available under aCC-BY-NC-ND 4.0 International license.

Hersch et al.

Engineering the T6SS

include a C-terminal tail for recruiting the effector, $\mathrm{TseH}(17)$. Full-length PAAR2 is only 176 amino acids

long, which is a significantly smaller 'T6S-tag' than the VgrG fusions; we hypothesized that the smaller

(PAAR2 $2_{\mathrm{FL}}$ ) or a truncated version (PAAR2 ${ }_{106}$ ) that has only 12 amino acids of the C-terminal tail (Fig. 2A).

171 Notably, since the VgrG1-Cre plasmid was used as a template, the cloning method left a 12 amino acid

172 remnant of $\operatorname{VgrG1}$ (codons 714-725, downstream of polyproline region); these residues act as a further

173 linker between PAAR2 and Cre.

Delivery of either PAAR2 $2_{\mathrm{FL}}-\mathrm{Cre}_{3 \mathrm{~V} 5}$ or PAAR2 ${ }_{106}-\mathrm{Cre}_{3 \mathrm{~V} 5}$ led to significant and substantial Cre-

175 mediated recombination in recipient cells (Fig. 2B). The number of Gent ${ }^{R}$ recipients following PAAR2 ${ }_{106^{-}}$

$176 \mathrm{Cre}_{3 \mathrm{v} 5}$ delivery was slightly higher than PAAR2 $\mathrm{FL}_{\mathrm{F}}-\mathrm{Cre}_{3 \mathrm{~V} 5}$, and comparable to the most effective fusion

177 tested previously, $\operatorname{VgrG3}_{717}$-Cre $_{3 \mathrm{~V} 5}$ (Fig. 2B compared to Fig. 1D). The no-Cre control (wild-type PAAR2)

178 and all $\Delta t s s M$ donors yielded undetectable or background amounts of recombination, demonstrating

179 that recombination in recipients required T6SS-mediated secretion of Cre. As expected, delivery of the

PAAR2-Cre fusions was also contact-dependent, since delivery in liquid media or with a barrier

separating the donor and recipient cells yielded negligible Gent ${ }^{R}$ C.F.U. (Fig. S3A, B). Importantly,

expression of the PAAR2-Cre fusions did not reduce donor cell fitness (Fig. S3C), suggesting that they did

not cause a fitness cost like the VgrG-Cre fusions. However, delivery of these fusions from wild-type

donor cells still demonstrated some toxicity to the recipients (Fig. S3D).

\section{Inactivating donor effectors restores recipient survival}

Despite using $V$. cholerae recipients - with all immunity genes intact - we consistently observed

188 some degree of toxicity towards the recipients that was independent of which Cre fusion was being 
Hersch et al.

Engineering the T6SS

strain showed no toxicity to recipients (Fig. S4A). Notably, delivery of VgrG-Cre fusions was reduced

when delivered from the $4 \mathrm{eff}_{\mathrm{C}}$ strain compared to the wild-type donor (Fig. S4B compared to Fig. 1D).

However, delivery of the PAAR2 ${ }_{106}-\mathrm{Cre}_{3 \mathrm{v} 5}$ fusion was similar from the $4 \mathrm{eff}_{\mathrm{C}}$ donor strain as from the wild-

type (Fig. S4B compared to Fig. 2B). These data support using the $4 \mathrm{eff}_{\mathrm{C}}$ strain to solve the recipient

toxicity issue.

\section{Measuring recombination efficiency and further improving efficacy}

Using the $4 \mathrm{eff}_{\mathrm{C}}$ donor strain, toxicity was prevented and total recipient recovery was consistent

regardless of which fusion construct was delivered (Fig. S4A). This allowed for measuring recombination the PAAR2 ${ }_{106}-\mathrm{Cre}_{3 v 5}$ construct (Fig. 2C).

207 efficiency for both $\operatorname{VgrG} 3_{717^{-}}$and PAAR2 ${ }_{106}$-Cre fusions (Fig. 2E), raising the efficiency to over $7 \%$. Oddly,

208 in the 6 His experiment (Fig. 2D), the PAAR2 ${ }_{106}-\mathrm{Cre}_{3 \mathrm{~V}}$ construct exhibited up to $10 \%$ recombination

209 efficiency, highlighting that there is some variability between experiments.

\section{T6SS effectors can serve as delivery vectors}

Up to this point we have demonstrated delivery of Cre as a fusion to T6SS structural genes,

213 VgrG1, VgrG3 and PAAR2 of $V$. cholerae. To further determine the versatility of T6SS-mediated protein

214 delivery, we fused Cre to the C-termini of the three V. cholerae cargo effectors, VasX, TseL and TseH (Fig. 
bioRxiv preprint doi: https://doi.org/10.1101/2021.05.11.443660; this version posted May 11, 2021. The copyright holder for this preprint (which

was not certified by peer review) is the author/funder, who has granted bioRxiv a license to display the preprint in perpetuity. It is made available under aCC-BY-NC-ND 4.0 International license.

Hersch et al.

Engineering the T6SS

3A). The VasX-Cre construct did not facilitate recombination in recipient cells (Fig 3B) or kill VasX-

216 sensitive prey (Fig. S5), suggesting that this fusion was inactive or failed to be secreted. However, both

217 TseL and TseH fusions demonstrated significant Cre delivery (Fig. 3B). The efficiency of TseH-Cre delivery

218 rivalled $\mathrm{VgrG}_{717}-\mathrm{Cre}_{3 \mathrm{~V} 5}$ but was lower than PAAR2 ${ }_{106}$ fusions (Fig. 3B compared to Fig. 2E). These findings

219 demonstrate that non-structural proteins can also serve as T6SS delivery tags to deliver customized

220 cargo proteins.

221

222

A. dhakensis is another proficient donor strain

We were curious if other species could also be employed for T6SS-mediated delivery of

224 recombinant proteins. We tested another aquatic species that has a constitutively active T6SS, $A$.

225 dhakensis strain SSU $(30,34)$. We fused Cre to each of the three VgrGs and two PAAR proteins present in

226 A. dhakensis (Fig. 3A). We then introduced these constructs into an A. dhakensis strain with its three

227 antibacterial effectors, Tsel, TseP and TseC, all catalytically inactivated (3eff $\mathrm{c})(35)$. This strain showed no

228 toxicity towards V. cholerae recipients (Fig. S6B)(35).

All three $\operatorname{VgrG}$ fusions led to significant Cre delivery from the $\mathrm{TCSS}^{+}$donor compared to an

230 equivalent $\Delta t s s M$ strain (Fig. $3 C$ ); delivery of $\operatorname{VgrG}_{A d}-C e_{3 v 5}$ yielded the highest recombination

231 efficiency. In contrast, neither of the $A$. dhakensis PAAR fusions demonstrated signs of delivery. Since

232 none of the $A$. dhakensis VgrG proteins have effector domains, we attempted to better mimic an

233 evolved VgrG by introducing a flexible linker between Cre and the VgrG domain (Fig. 3A). The linker

234 appeared to improve delivery for $\operatorname{VgrG} 2_{A d}$ and $\operatorname{VgrG} 3_{A d}$, but not $\operatorname{VgrG1} 1_{A d}$ (Fig. $3 C$ ). Notably, none of the

235 fusion constructs appeared to inhibit donor fitness and the $3 \mathrm{eff}_{\mathrm{C}}$ strain showed no recipient toxicity

236 compared to the $\Delta t s s M$ strain (Fig. S6). Cumulatively, these findings demonstrate that the T6SS of

237 multiple species can be engineered to deliver active Cre recombinase. Additionally, this transfer can 
Hersch et al.

Engineering the T6SS

cross species barriers ( $A$. dhakensis delivery to $V$. cholerae recipients) if the donor's antibacterial

effectors are inactivated.

We also examined delivery to a recipient strain with a chromosomal copy of FIGR instead of the pFIGR plasmid (approximately 20 copies per cell). Delivery of the $\operatorname{VgrG3}_{\mathrm{Ad}^{-}-\mathrm{L}-\mathrm{Cre}} \mathrm{Bv}_{5}$ fusion from $A$. be less efficient than the plasmid-borne cassette.

The PAAR2 ${ }_{106}$ T6S tag enables $V$. cholerae to deliver a recombinant effector to kill $P$. aeruginosa maximize efficacy against particular prey. As a proof-of-principle, we employed $V$. cholerae and $P$. against $P$. aeruginosa; alternatively, the $V$. cholerae T6SS might not be able to puncture the $P$. aeruginosa cell envelope to deliver the effectors $(17,27,36)$. catalytically inactivating (Fig. 4A). By inactivating two effectors at a time - leaving a single active effector

257 in the strain - we determined that TseP and TseC were effective against $P$. aeruginosa and TseC was more consistent (Fig. 4A). In light of this, we replaced Cre (of the PAAR2 ${ }_{106}$-Cre fusion) with TseC and its

259 downstream immunity gene (tsiC) from $A$. dhakensis. Both wild-type and the $4 \mathrm{eff}_{\mathrm{C}}$ strain of $V$. cholerae were able to deliver this PAAR2 ${ }_{106}-T s e C_{A d}$ fusion, resulting in greatly reduced survival of competing $V$. 
bioRxiv preprint doi: https://doi.org/10.1101/2021.05.11.443660; this version posted May 11, 2021. The copyright holder for this preprint (which

was not certified by peer review) is the author/funder, who has granted bioRxiv a license to display the preprint in perpetuity. It is made available under aCC-BY-NC-ND 4.0 International license.

Hersch et al.

Engineering the T6SS

262

263

264

265

266

267

268

269

270

271

272

273

274

275

276

277

278

279

280

281

282

283

284

285

to kill P. aeruginosa (Fig. 4C). Importantly, this was T6SS- and $\mathrm{TseC}_{A d}$-dependent, suggesting that reduced $P$. aeruginosa survival results from T6SS-mediated delivery of the $A$. dhakensis effector from $V$. cholerae. Accordingly, V. cholerae delivering PAAR2 ${ }_{106}-\mathrm{TseC}_{A d}$ inhibited $P$. aeruginosa to a similar degree as the $A$. dhakensis strain with TseC as its only active effector (Fig. 4A compared to C).

\section{Discussion}

In this work we developed multiple fusion tags allowing the T6SSs of $V$. cholerae and $A$.

dhakensis to efficiently deliver the targeted endonuclease, Cre, or an exogenous effector, $\mathrm{TseC}_{A d}$ directly into neighbouring cells (Fig. 5). We also showed activity of the system with a 6His-tagged protein, potentially leading to a downstream method for lysis-free purification of secreted fusion proteins. Additionally, we constructed a novel gain-of-function Cre detection cassette (FIGR) and identified the $A$. dhakensis T6SS effectors that are most active against $P$. aeruginosa.

The delivery fusion results described in this work reveal details of T6SS function. For instance, since Cre was able to access the DNA of recipient cells, it implicates that the T6SS tip can puncture into the cytoplasm. This supports previous works using nuclease effectors, the reuse of secreted T6SS components in recipient sister cells, and the finding that $\operatorname{VgrG} 3$ of $V$. cholerae has evolved to re-export from the cytoplasm of recipient cells to access its peptidoglycan target in the periplasm(22, 37). Another finding was that Cre could be delivered as a fusion to PAAR2 of $V$. cholerae but not when fused to either PAAR protein of $A$. dhakensis. Likely, this results from the extended C-terminal domain of PAAR2 that is not present in the other PAAR proteins. This region acts as a linker (even when truncated in the PAAR2 ${ }_{106}$ construct) that potentially improves the folding or functionality of Cre or the PAAR domain.

This suggests that effectors that are attached to PAAR domains must include a sufficient linker or else impede folding or functionality. 
bioRxiv preprint doi: https://doi.org/10.1101/2021.05.11.443660; this version posted May 11, 2021. The copyright holder for this preprint (which

was not certified by peer review) is the author/funder, who has granted bioRxiv a license to display the preprint in perpetuity. It is made available under aCC-BY-NC-ND 4.0 International license.

Hersch et al. Engineering the T6SS

We employed the PAAR2 ${ }_{106}$ T6S tag to engineer $V$. cholerae to deliver the $A$. dhakensis effector,

287 TseC. This led to a number of significant findings: 1) TseC was fully active when delivered from $V$.

288 cholerae, suggesting that TseC's chaperone (TEC) protein is not required for proper folding or

activity(30). However, V. cholerae also encodes two DUF4123 TEC proteins, so it remains possible that

they can act in lieu of the $A$. dhakensis chaperone(30). 2) Since the tseC fusion gene demonstrated full

291

activity after switching to a new host organism and delivery mechanism, this provides further empirical

292

evidence that domain swapping can facilitate new effector integration. This supports previous works

examining the evolution of the T6SS by horizontal gene transfer and the modular nature of effectors(22,

38-41).

The findings additionally highlight the evolutionary advantage of accumulating exogenous

effectors since $V$. cholerae equipped with PAAR2 ${ }_{106}-T s e C$ devastated neighbouring $V$. cholerae

297 populations (Fig. 4B). Moreover, it gained the ability to kill $P$. aeruginosa, which suggests that the $V$.

298 cholerae T6SS is capable of delivering effectors into $P$. aeruginosa but these prey cells have the ability to

299 resist killing by all four of $V$. cholerae's natural antibacterial T6SS effectors. This resistance may not be

complete, as delivery of $V$. cholerae effectors can instigate a retaliatory 'tit-for-tat' response in $P$.

301

aeruginosa $(17,27)$. Additionally, delivering PAAR2 ${ }_{106}-\mathrm{TseC}_{A d}$ from the wild-type donor appeared to kill $P$.

aeruginosa more than delivery from the $4 \mathrm{eff}_{\mathrm{C}}$ strain, suggesting that there may be some level of synergy

between TseC and the $V$. cholerae effectors. Nonetheless, the $V$. cholerae effectors alone did not

significantly reduce $P$. aeruginosa survival. The mechanism of this resistance remains to be determined

in future work but could involve cross-protection by $P$. aeruginosa's array of immunity genes or 
bioRxiv preprint doi: https://doi.org/10.1101/2021.05.11.443660; this version posted May 11, 2021. The copyright holder for this preprint (which

was not certified by peer review) is the author/funder, who has granted bioRxiv a license to display the preprint in perpetuity. It is made available under aCC-BY-NC-ND 4.0 International license.

Hersch et al.

Engineering the T6SS

The antibacterial activity of the T6SS can be harnessed to target specific species for

manipulating microbiomes or as a potential next-generation antimicrobial $(21,22,45)$. To achieve this, it

311 is crucial to be able to equip the T6SS with a customized selection of effectors. Effector discovery used

312 to be a major challenge of the field due to sequence divergence, but multiple approaches have been

313 developed to overcome this earlier challenge(23, 30, 46-48). Now the pool of divergent effectors

314 comprises thousands of proteins in hundreds of species, including many that are genetically intractable.

315 Thus, the ability to swap an effector into a different T6SS delivery species will allow for further study of

316 effectors - and defences against them - in isolation from their native delivery strains. The fusions

317 described here establish delivery mechanisms for auxiliary effectors to maximize efficacy against

318 particular target species, thereby enhancing the potential of the T6SS for future applications.

Finally, the engineered T6SS provides advantages over existing platforms for delivery of genetic

editing enzymes as proteins: 1) The T6SS can deliver directly into the target cell cytoplasm without

321 requiring a receptor. This grants an advantage over secreted proteins, which require receptors for

322 uptake, deliver only to the periplasm of bacteria, or both. 2) The T6SS can deliver ready-folded proteins,

323 providing an advantage over T3SSs or T4SSs for cargo that is inactivated by denaturation. 3) Due to its

324 receptor-independent mechanism, the T6SS has a broad spectrum of target cells including both

325 eukaryotic and prokaryotic cells. The system described here provides the first example of delivering a

326 genetic editing enzyme as a protein into bacteria.

Throughout the process of optimizing the T6SS delivery fusions, we employed Cre recombinase.

328 Notably, Cre acts as a tetramer, requiring at least four molecules to be delivered to recipients before

329 recombination can occur. Since three VgrG proteins are delivered per firing event, the VgrG-Cre fusions

330 potentially deliver multiple Cre molecules at once. However, it is not known if the VgrG trimer

331 dissociates in recipient cells or if Cre instigates recombination while still assembled in a VgrG trimer. In

332 contrast, the PAAR ${ }_{106}$ fusion tag can only deliver one protein per T6SS firing event but may promote Cre 
bioRxiv preprint doi: https://doi.org/10.1101/2021.05.11.443660; this version posted May 11, 2021. The copyright holder for this preprint (which

was not certified by peer review) is the author/funder, who has granted bioRxiv a license to display the preprint in perpetuity. It is made available under aCC-BY-NC-ND 4.0 International license.

Hersch et al.

Engineering the T6SS

functionality due to the smaller T6S tag domain. Because it functions as a tetramer, Cre recombination

likely understates delivery efficiency, which may increase with the use of monomeric enzymes in the

future.

In addition to the immediate potential applications of Cre delivery, it primarily acts as a proof-

of-principle: The successful delivery of Cre - and subsequent recombination in recipient cells - marks an delivery system.

\section{Materials and Methods}

\section{Bacterial strains and growth conditions}


bioRxiv preprint doi: https://doi.org/10.1101/2021.05.11.443660; this version posted May 11, 2021. The copyright holder for this preprint (which

was not certified by peer review) is the author/funder, who has granted bioRxiv a license to display the preprint in perpetuity. It is made available under aCC-BY-NC-ND 4.0 International license.

Hersch et al.

Engineering the T6SS

\section{Plasmid construction}

Plasmids used in this study are listed in Supplementary Table S1B. Plasmids were generated

using Gibson cloning(50) or overlapping PCR mutagenesis(51) and verified by Sanger sequencing. In

brief, pFIGR was generated by first inserting loxP sites on both sides of the ampicillin resistance cassette

of $\mathrm{pBAD24}$. This floxed $\mathrm{Amp}^{\mathrm{R}}$ gene was then inserted (in the reverse-direction) before the second codon

of the gentamicin resistance gene in pPSV37. For chromosomal FIGR, a version of FIGR with Kan ${ }^{R}$ instead

of $A m p^{R}\left(F_{I G R}\right.$ kan was transferred into the pGP-Tn7 plasmid allowing for transposon-mediated insertion

(with the pSTNSK helper plasmid) at the chromosomal attTn7 site(52).

Delivery fusions were generated in the pBAD33 plasmid backbone (arabinose inducible,

PAAR2 $_{\mathrm{FL}}$ or PAAR2 ${ }_{106}$, leaving a 12 amino acid remnant of VgrG1 as a linker between PAAR2 and Cre.

Subsequent effector, $A$. dhakensis, and TseC fusions were generated by Gibson cloning to replace VgrG

371 or Cre in existing plasmids.

\section{Secretion assay and western blot}

Secretion assays were conducted similar to described previously(16). In brief, strains were

375 grown for 3 hours with arabinose added to $0.4 \%$ to induce fusion gene expression. Cultures were

376 centrifuged and pellets stored for sonication as cell lysate samples. Meanwhile supernatants were

377 passed through $0.22 \mu \mathrm{m}$ filters, trichloroacetic acid (TCA) solution was added to final concentration of

$37820 \%$, and placed at $-20^{\circ} \mathrm{C}$ overnight. Supernatants were then centrifuged at $15,000 \mathrm{~g}$ for $20 \mathrm{~min}$ at $4{ }^{\circ} \mathrm{C}$,

379 pellets washed with $100 \%$ acetone, and the resultant pellet resuspended in SDS-loading dye for analysis 
bioRxiv preprint doi: https://doi.org/10.1101/2021.05.11.443660; this version posted May 11, 2021. The copyright holder for this preprint (which

was not certified by peer review) is the author/funder, who has granted bioRxiv a license to display the preprint in perpetuity. It is made available under aCC-BY-NC-ND 4.0 International license.

Hersch et al. Engineering the T6SS

As described previously $(15,53)$, proteins were resolved by polyacrylamide gel electrophoresis,

transferred to a nitrocellulose membrane, blocked with 5\% skim milk in TBST buffer (50 mM Tris, 150

$\mathrm{mM} \mathrm{NaCl}$, and $0.05 \%$ Tween $20, \mathrm{pH} 7.6$ ) for $1 \mathrm{~h}$ at room temperature, then incubated with primary

antibodies overnight at $4{ }^{\circ} \mathrm{C}$. Blots were washed 3 times in TBST, incubated with anti-mouse HRP-

conjugated secondary antibody (Cell Signaling Technology) for $1 \mathrm{~h}$, then detected using ECL solution

(Bio-Rad). Monoclonal antibodies to the V5 epitope tag and RpoB, the beta subunit of RNA polymerase

used as a cytoplasmic control, were purchased from GeneTex and NeoClone, respectively.

\section{T6SS competition and delivery assays}

T6SS activity assays were conducted similar to described previously with minor

modifications(17): 'Donor' or 'killer' strains were subcultured in LB (with antibiotic for plasmid

maintenance as needed) for 3 hours with arabinose added to $0.4 \%$ ( $0.01 \%$ for $A$. dhakensis) for the last

hour. 'Recipient' or 'prey' strains were from overnight cultures. For wild-type Cre donors and equivalent

controls, donor and recipient were mixed at a 5:1 ratio. Competition assays and donor experiments with

V. cholerae $4 \mathrm{eff}_{\mathrm{C}}$ (or A. dhakensis 3 eff ${ }_{C}$ ) donors employed 10:1 ratios. Mixtures were spotted on LB

PBS, serially diluted and plated for colony forming units (C.F.U.) on LB plates containing antibiotics as 
Hersch et al.

Engineering the T6SS

\section{$\underline{\text { References }}$}

407 1. Nagy A. 2000. Cre recombinase: the universal reagent for genome tailoring. Genes (New York, NY

408 2000) 26:99-109.

409 2. Sternberg N, Hamilton D. 1981. Bacteriophage P1 site-specific recombination. I. Recombination between loxP sites. J Mol Biol 150:467-486.

$4113 . \quad$ Song AJ, Palmiter RD. 2018. Detecting and Avoiding Problems When Using the Cre-lox System. Trends Genet 34:333-340.

4. Lino CA, Harper JC, Carney JP, Timlin JA. 2018. Delivering CRISPR: a review of the challenges and approaches. Drug Deliv 25:1234-1257.

5. Uddin F, Rudin CM, Sen T. 2020. CRISPR Gene Therapy: Applications, Limitations, and Implications for the Future. Front Oncol 10:1387.

417 6. Costa TRD, Felisberto-Rodrigues C, Meir A, Prevost MS, Redzej A, Trokter M, Waksman G. 2015. Microbiol 13:343-359.

420 7. Bai F, Li Z, Umezawa A, Terada N, Jin S. 2018. Bacterial type III secretion system as a protein delivery tool for a broad range of biomedical applications. Biotechnol Adv 36:482-493.

422 8. Walker BJ, Stan G-B V, Polizzi KM. 2017. Intracellular delivery of biologic therapeutics by bacterial secretion systems. Expert Rev Mol Med 19:e6.

424 9. Pukatzki S, Ma AT, Sturtevant D, Krastins B, Sarracino D, Nelson WC, Heidelberg JF, Mekalanos JJ. 2006. Identification of a conserved bacterial protein secretion system in Vibrio cholerae using the Dictyostelium host model system. Proc Natl Acad Sci U S A 103:1528-1533.

427 10. Mougous JD, Cuff ME, Raunser S, Shen A, Zhou M, Gifford CA, Goodman AL, Joachimiak G, 
bioRxiv preprint doi: https://doi.org/10.1101/2021.05.11.443660; this version posted May 11, 2021. The copyright holder for this preprint (which

was not certified by peer review) is the author/funder, who has granted bioRxiv a license to display the preprint in perpetuity. It is made available under aCC-BY-NC-ND 4.0 International license.

Hersch et al. Engineering the T6SS

aeruginosa encodes a protein secretion apparatus. Science 312:1526-1530.

43011 Coulthurst S. 2019. The Type VI secretion system: a versatile bacterial weapon. Microbiology 165:503-515.

12. Jana B, Salomon D. 2019. Type VI secretion system: a modular toolkit for bacterial dominance. Future Microbiol 14:1451-1463.

13. Ma L-S, Hachani A, Lin J-S, Filloux A, Lai E-M. 2014. Agrobacterium tumefaciens deploys a superfamily of type VI secretion DNase effectors as weapons for interbacterial competition in planta. Cell Host Microbe 16:94-104.

14. Ringel PD, Hu D, Basler M. 2017. The Role of Type VI Secretion System Effectors in Target Cell Lysis and Subsequent Horizontal Gene Transfer. Cell Rep 21:3927-3940.

15. Liang X, Kamal F, Pei T-T, Xu P, Mekalanos JJ, Dong TG. 2019. An onboard checking mechanism ensures effector delivery of the type VI secretion system in Vibrio cholerae. Proc Natl Acad Sci

16. Kamal F, Liang X, Manera K, Pei T-T, Kim H, Lam LG, Pun A, Hersch SJ, Dong TG. 2020. Differential Secretion System. Cell Rep 31:107766.

17. Hersch SJ, Watanabe N, Stietz MS, Manera K, Kamal F, Burkinshaw B, Lam L, Pun A, Li M,

18. Wettstadt S, Lai E-M, Filloux A. 2020. Solving the Puzzle: Connecting a Heterologous Cell Infect Microbiol 10:291. 
bioRxiv preprint doi: https://doi.org/10.1101/2021.05.11.443660; this version posted May 11, 2021. The copyright holder for this preprint (which

was not certified by peer review) is the author/funder, who has granted bioRxiv a license to display the preprint in perpetuity. It is made available under aCC-BY-NC-ND 4.0 International license.

Hersch et al.

Engineering the T6SS

20. Jiang F, Wang X, Wang B, Chen L, Zhao Z, Waterfield NR, Yang G, Jin Q. 2016. The Pseudomonas aeruginosa Type VI Secretion PGAP1-like Effector Induces Host Autophagy by Activating Endoplasmic Reticulum Stress. Cell Rep 16:1502-1509.

21. Wettstadt S, Filloux A. 2020. Manipulating the type VI secretion system spike to shuttle passenger proteins. PLoS One 15:e0228941.

22. Ho BT, Fu Y, Dong TG, Mekalanos JJ. 2017. Vibrio cholerae type 6 secretion system effector trafficking in target bacterial cells. Proc Natl Acad Sci U S A 114:9427-9432.

23. Dong TG, Ho BT, Yoder-Himes DR, Mekalanos JJ. 2013. Identification of T6SS-dependent effector and immunity proteins by Tn-seq in Vibrio cholerae. Proc Natl Acad Sci U S A 110:2623-2628.

24. Miyata ST, Unterweger D, Rudko SP, Pukatzki S. 2013. Dual Expression Profile of Type VI Secretion System Immunity Genes Protects Pandemic Vibrio cholerae. PLOS Pathog 9:e1003752.

25. Wong M, Liang X, Smart M, Tang L, Moore R, Ingalls B, Dong TG. 2016. Microbial herd protection mediated by antagonistic interaction in polymicrobial communities. Appl Environ Microbiol 82:6881-6888.

26. Altindis E, Dong T, Catalano C, Mekalanos J. 2015. Secretome analysis of Vibrio cholerae type VI secretion system reveals a new effector-immunity pair. MBio 6:e00075-15.

27. Basler M, Ho BT, Mekalanos JJ. 2013. Tit-for-tat: type VI secretion system counterattack during bacterial cell-cell interactions. Cell 152:884-894.

471 28. Brooks TM, Unterweger D, Bachmann V, Kostiuk B, Pukatzki S. 2013. Lytic activity of the Vibrio 7625.

474 29. Pukatzki S, Ma AT, Revel AT, Sturtevant D, Mekalanos JJ. 2007. Type VI secretion system 
bioRxiv preprint doi: https://doi.org/10.1101/2021.05.11.443660; this version posted May 11, 2021. The copyright holder for this preprint (which

was not certified by peer review) is the author/funder, who has granted bioRxiv a license to display the preprint in perpetuity. It is made available under aCC-BY-NC-ND 4.0 International license.

Hersch et al. Engineering the T6SS

477

478

479

480

481

482

483

484

485

486

487

488

489

490

491

492

493

494

495

496

497

498

499

500

30. Liang X, Moore R, Wilton M, Wong MJQ, Lam L, Dong TG. 2015. Identification of divergent type VI secretion effectors using a conserved chaperone domain. Proc Natl Acad Sci 112:9106-9111.

31. Unterweger D, Kostiuk B, Otjengerdes R, Wilton A, Diaz-Satizabal L, Pukatzki S. 2015. Chimeric adaptor proteins translocate diverse type VI secretion system effectors in Vibrio cholerae. EMBO J 34:2198-2210.

32. Bichsel C, Neeld DK, Hamazaki T, Wu D, Chang L-J, Yang L, Terada N, Jin S. 2011. Bacterial delivery of nuclear proteins into pluripotent and differentiated cells. PLoS One 6:e16465.

33. Marchler-Bauer A, Bo Y, Han L, He J, Lanczycki CJ, Lu S, Chitsaz F, Derbyshire MK, Geer RC, Gonzales NR, Gwadz M, Hurwitz DI, Lu F, Marchler GH, Song JS, Thanki N, Wang Z, Yamashita RA, Zhang D, Zheng C, Geer LY, Bryant SH. 2017. CDD/SPARCLE: functional classification of proteins via subfamily domain architectures. Nucleic Acids Res 45:D200-D203.

34. Suarez G, Sierra JC, Sha J, Wang S, Erova TE, Fadl AA, Foltz SM, Horneman AJ, Chopra AK. 2008. Molecular characterization of a functional type VI secretion system from a clinical isolate of Aeromonas hydrophila. Microb Pathog 44:344-361.

35. Liang X, Pei T-T, Wang Z-H, Xiong W, Wu L-L, Xu P, Lin S, Dong TG. 2021. Characterization of a lysozyme-like effector TseP and secretion co-dependence of the type VI secretion system in Aeromonas dhakensis SSU. Appl Environ Microbiol.

36. Toska J, Ho BT, Mekalanos JJ. 2018. Exopolysaccharide protects Vibrio cholerae from exogenous attacks by the type 6 secretion system. Proc Natl Acad Sci U S A2018/07/18. 115:7997-8002.

37. Vettiger A, Basler M. 2016. Type VI Secretion System Substrates Are Transferred and Reused among Sister Cells. Cell 167:99-110.e12.

38. Thomas J, Watve SS, Ratcliff WC, Hammer BK. 2017. Horizontal Gene Transfer of Functional Type VI Killing Genes by Natural Transformation. MBio 8.

39. Kirchberger PC, Unterweger D, Provenzano D, Pukatzki S, Boucher Y. 2017. Sequential 
bioRxiv preprint doi: https://doi.org/10.1101/2021.05.11.443660; this version posted May 11, 2021. The copyright holder for this preprint (which

was not certified by peer review) is the author/funder, who has granted bioRxiv a license to display the preprint in perpetuity. It is made available under aCC-BY-NC-ND 4.0 International license.

Hersch et al.

Engineering the T6SS

displacement of Type VI Secretion System effector genes leads to evolution of diverse immunity gene arrays in Vibrio cholerae. Sci Rep 7:45133.

40. Unterweger D, Miyata ST, Bachmann V, Brooks TM, Mullins T, Kostiuk B, Provenzano D, Pukatzki

S. 2014. The Vibrio cholerae type VI secretion system employs diverse effector modules for intraspecific competition. Nat Commun 5:3549.

506

41. Salomon D, Klimko JA, Trudgian DC, Kinch LN, Grishin N V, Mirzaei H, Orth K. 2015. Type VI 11:e1005128.

42. LaCourse KD, Peterson SB, Kulasekara HD, Radey MC, Kim J, Mougous JD. 2018. Conditional toxicity and synergy drive diversity among antibacterial effectors. Nat Microbiol2018/02/19. $3: 440-446$.

43. Wood TE, Howard SA, Forster A, Nolan LM, Manoli E, Bullen NP, Yau HCL, Hachani A, Hayward RD, Whitney JC, Vollmer W, Freemont PS, Filloux A. 2019. The Pseudomonas aeruginosa T6SS Delivers a Periplasmic Toxin that Disrupts Bacterial Cell Morphology. Cell Rep 29:187-201.e7.

44. Trunk K, Peltier J, Liu Y-C, Dill BD, Walker L, Gow NAR, Stark MJR, Quinn J, Strahl H, Trost M, Coulthurst SJ. 2018. The type VI secretion system deploys antifungal effectors against microbial competitors. Nat Microbiol 3:920-931.

45. Ting S-Y, Martínez-García E, Huang S, Bertolli SK, Kelly KA, Cutler KJ, Su ED, Zhi H, Tang Q, Radey MC, Raffatellu M, Peterson SB, de Lorenzo V, Mougous JD. 2020. Targeted Depletion of Bacteria from Mixed Populations by Programmable Adhesion with Antagonistic Competitor Cells. Cell Host Microbe 28:313-321.e6.

522 46. Salomon D, Kinch LN, Trudgian DC, Guo X, Klimko JA, Grishin N V, Mirzaei H, Orth K. 2014. Marker for type VI secretion system effectors. Proc Natl Acad Sci U S A 111:9271-9276. 
bioRxiv preprint doi: https://doi.org/10.1101/2021.05.11.443660; this version posted May 11, 2021. The copyright holder for this preprint (which

was not certified by peer review) is the author/funder, who has granted bioRxiv a license to display the preprint in perpetuity. It is made available under aCC-BY-NC-ND 4.0 International license.

Hersch et al. Engineering the T6SS

sharpen and diversify the type VI secretion system spike. Nature 500:350-353.

526

48. Hood RD, Singh P, Hsu F, Güvener T, Carl MA, Trinidad RRS, Silverman JM, Ohlson BB, Hicks KG,

Plemel RL, Li M, Schwarz S, Wang WY, Merz AJ, Goodlett DR, Mougous JD. 2010. A type VI

528

secretion system of Pseudomonas aeruginosa targets a toxin to bacteria. Cell Host Microbe 7:25-

529

37.

530

49. Burkinshaw BJ, Liang X, Wong M, Le ANH, Lam L, Dong TG. 2018. A type VI secretion system

effector delivery mechanism dependent on PAAR and a chaperone-co-chaperone complex. Nat

Microbiol 3:632-640.

533

50. Gibson DG, Young L, Chuang R-Y, Venter JC, Hutchison CA, Smith HO. 2009. Enzymatic assembly of DNA molecules up to several hundred kilobases. Nat Meth 6:343-345.

51. Hersch SJ, Elgamal S, Katz A, Ibba M, Navarre WW. 2014. Translation initiation rate determines the impact of ribosome stalling on bacterial protein synthesis. J Biol Chem 289.

52. Crepin S, Harel J, Dozois CM. 2012. Chromosomal complementation using Tn7 transposon vectors in Enterobacteriaceae. Appl Environ Microbiol 78:6001-6008.

53. Stietz MS, Liang X, Wong M, Hersch S, Dong TG. 2020. Double tubular contractile structure of the type VI secretion system displays striking flexibility and elasticity. J Bacteriol 202.

\section{Corresponding author}

545 tdong@ucalgary.ca 
bioRxiv preprint doi: https://doi.org/10.1101/2021.05.11.443660; this version posted May 11, 2021. The copyright holder for this preprint (which

was not certified by peer review) is the author/funder, who has granted bioRxiv a license to display the preprint in perpetuity. It is made available under aCC-BY-NC-ND 4.0 International license.

Hersch et al. Engineering the T6SS

This work was supported by grants from Canadian Institutes of Health Research (CIHR) and

550 Canadian Natural Sciences and Engineering Research Council (NSERC) to T.G.D.. T.G.D. is also supported

551 by a Government of Canada Research Chair award, and a Canadian Foundation for Innovation grant (CFI-

552 JELF). L.L. was supported by an Alberta Innovates Health Solutions (AlHS) Graduate Student Scholarship,

553 and S.J.H. holds a CIHR Postdoctoral Fellowship.

554

555

Author contributions

S.J.H. and T.G.D. conceived the project, S.J.H. and L.L. generated fusion constructs, S.J.H.

designed, performed and analysed experiments, as well as prepared the original manuscript and figures.

T.G.D. supervised the study and guided manuscript revision.

\section{Competing interests}

The authors declare no competing interests.

Figure legends

Figure 1: Active VgrG-Cre fusions are secreted and delivered to recipient cells in a T6SS-dependent

570 an actin cross-linking domain (red; ACD). VgrG3 (blue) wild-type includes a lysozyme domain (red) with a

571 linker region leading up to the peptidoglycan binding domain beginning at codon 718. nc, 'no Cre'. B.

572 Western blot showing secretion of VgrG1 and VgrG3 fusions from wild-type V. cholerae V52 but not an 
Hersch et al.

equivalent tssM mutant. 'Sec' (top) shows secreted fractions, 'Cell' (bottom) shows cell pellet lysates. In

574 addition to $\alpha-V 5, \alpha-R p o B$ antibody was included as a cytoplasm control. Representative of three

575 independent replicates. C. Depiction of the 'Floxed Interruption in Gentamicin Resistance' (FIGR)

576 cassette. An ampicillin resistance cassette (purple) - encoded in the reverse direction and flanked by

577 loxP sites (red) - interrupts the open reading frame of a gentamicin resistance gene (yellow striped).

578 Exposure to Cre removes the block and allows expression of the gentamicin resistance gene (yellow).

579 Promoters are shown as $90^{\circ}$ arrows. Figure is not to scale. ATG, Gent ${ }^{R}$ start codon. D. Recovery of $V$. 580 cholerae Gent $^{R}$ colony forming units (indicative of Cre-mediated FIGR cassette recombination) after 581 delivery from wild-type (+) or $\Delta \operatorname{tss} M(\Delta)$ V. cholerae with indicated Cre fusions to VgrG vectors. DL, 582 detection limit. One-way ANOVA with Sidak's multiple comparison test comparing wild-type and $\Delta t s s M$ 583 donors with equivalent delivery fusions. Recovery from $\Delta t s s M$ samples were not significantly above 'Cre 584 only' or 'no Cre (nc)' controls. ${ }^{* *}, \mathrm{p}<0.01 ; * * *, p<0.001$.

590 (codons 714-725) used as template for PAAR2 insertion. B. Recovery of Cre-recombined recipient 
Hersch et al.

multiple comparison test comparing each sample to the $\Delta t s s M$ donor strain. ${ }^{* * *}, \mathrm{p}<0.001$; ns, not

Tukey's multiple comparison test. ${ }^{* * *}, \mathrm{p}<0.001 ; \mathrm{ns}$, not significant. E. Recombination efficiency after delivery from $4 \mathrm{eff}_{\mathrm{C}}$ strain encoding indicated Cre fusions with the $3 \mathrm{~V} 5$ tag present $(+)$ or removed (-). DL, approximate detection limit. One-way ANOVA with Sidak's multiple comparison test comparing samples with and without $3 \mathrm{~V} 5$ tags. ${ }^{*}, \mathrm{p}<0.05 ;$ ns, not significant. sample to the $\Delta$ tss $M$ donor. ${ }^{*}, p<0.05 ;{ }^{* *}, p<0.01 ;{ }^{* *}, p<0.001 ;$ ns, not significant.

aeruginosa. A. Prey $P$. aeruginosa recovery after incubation with $A$. dhakensis killer cells. Prey $P$.

618 aeruginosa has $\Delta h s i B(\Delta t s s B)$ mutations in all three T6SS. Killer strains have T6SS-null mutation $(\Delta t s s M)$ 
Hersch et al.

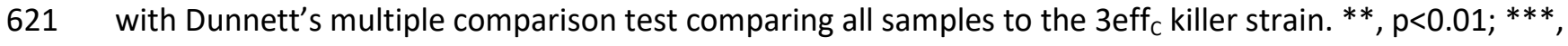

$622 p<0.001 ;$ ns, not significant. B. Prey V. cholerae $(\Delta t s s M)$ recovery after incubation with $V$. cholerae killer

623 cells encoding PAAR2 $2_{106}$ fusions to $A$. dhakensis $\mathrm{TseC}\left(\mathrm{TseC}_{A d}\right)$ or Cre as a control. Killer strains have

$624 \Delta \operatorname{sss} M(\Delta)$ or a wild-type T6SS with all effectors intact (wt) or all native antibacterial effectors

625 catalytically inactivated $\left(4 \mathrm{eff}_{\mathrm{C}}\right)$. DL, detection limit. One-way ANOVA with Sidak's multiple comparison

test. ${ }^{* * *}, \mathrm{p}<0.001 ; \mathrm{ns}$, not significant. C. Prey $P$. aeruginosa ( $\Delta h \operatorname{siB}$ mutations in all three T6SS) recovery

627 after incubation with $V$. cholerae killer cells with no fusion construct (n/a) or encoding PAAR2 ${ }_{106}$ fusions

628 to $A$. dhakensis $\mathrm{TseC}\left(\mathrm{TseC}_{A d}\right)$ or Cre as a control. Killer strains have $\Delta \operatorname{tss} M(\Delta)$ or a wild-type T6SS with

629 all effectors intact (wt) or all native antibacterial effectors catalytically inactivated $\left(4 \mathrm{eff}_{\mathrm{c}}\right)$. One-way

630 ANOVA with Sidak's multiple comparison test. ${ }^{* *}, \mathrm{p}<0.01 ; * * *, p<0.001 ; \mathrm{ns}$, not significant.

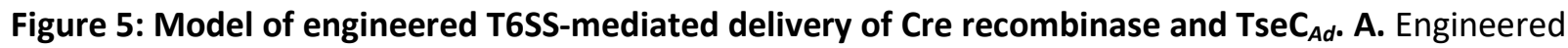

\section{Supplemental Material legends}

641 competition assay showing killing by wild-type V52 (WT), or a V52 strain lacking the vgrG1 gene

642 ( $\Delta v g r G 1)$ and complemented with no plasmid (n/a), $\operatorname{VgrG1} 1_{725}-\mathrm{Cre}_{3 \mathrm{~V} 5}$, or $\mathrm{VgrG}_{717}-\mathrm{Cre}_{3 \mathrm{~V} 5}$. Prey are a V52

643 strain lacking the TseL immunity gene, tsiV1, and complemented with either empty vector (pVec) or

644 tsiV1 on a plasmid (plmm). Survival of the prey is shown as a ratio of recovered C.F.U. (pVec / plmm). 
Hersch et al.

One-way ANOVA with Dunnett's multiple comparison test comparing each killer strain to $\Delta v g r G 1$ with

no plasmid. ${ }^{* *}, \mathrm{p}<0.01 ;{ }^{* *}, \mathrm{p}<0.001 ; \mathrm{ns}$, not significant.

\section{Supplemental Figure S2: VgrG fusions total donor and recipient survival, liquid or barrier controls,}

related to Figure 1D. A. Recovery of $V$. cholerae $\operatorname{Kan}^{R}$ (total recipients) or Carb ${ }^{R}$ (recipients with at least not significant 
Hersch et al.

670 incubation with $V$. cholerae FIGR recipients. One-way ANOVA analysis indicates no significant

671 differences. D. Recovery of $V$. cholerae $\operatorname{Kan}^{R}$ (total recipients) colony forming units after delivery from

672 active T6SS $(+)$ or $\Delta \operatorname{tss} M(\Delta)$ V. cholerae with indicated Cre fusions to PAAR2 vectors. One-way ANOVA

673 with Sidak's multiple comparison test comparing active T6SS and $\Delta t s s M$ donors with comparable delivery fusions. ${ }^{* *}, \mathrm{p}<0.01 ; * * *, \mathrm{p}<0.001$.

675

Supplemental Figure S4: Cre fusion delivery from effectorless donor strain, related to Figure 2C. A.

677 Total recipients recovered (Kan ${ }^{R}$ C.F.U.) after delivery from $V$. cholerae with catalytically inactivated

678 antibacterial effectors $\left(4 \mathrm{eff}_{\mathrm{C}}\right.$ ) or $\Delta \operatorname{tss} M(\Delta)$. One-way ANOVA with Dunnett's multiple comparison test

679 comparing each sample to the $\Delta t s s M$ donor strain. ${ }^{* * *}, \mathrm{p}<0.001 ; \mathrm{ns}$, not significant. B. As for A. but

680 showing Cre-recombined recipient bacteria (Gent ${ }^{R}$ C.F.U). DL, detection limit. One-way ANOVA analysis

681 indicates no significant differences.

Supplemental Figure S5: The VasX-Cre fusion does not kill sensitive prey. T6SS competition assay showing killing by V52 wild-type (WT), catalytically inactivated antibacterial effectors $\left(4 \mathrm{eff}_{\mathrm{c}}\right)$, or strain lacking the VasX immunity gene, tsiV2, and complemented with either tsiV2 (plmm) or a nonprotective chaperone gene as a control (VCA0019; pCtrl). Survival of the prey is shown as a ratio of recovered C.F.U. (pCtrl / plmm). One-way ANOVA with Sidak's multiple comparison test comparing no plasmid WT or VasX-Cre delivery to controls. ${ }^{* * *}, \mathrm{p}<0.001 ; \mathrm{ns}$, not significant. 
bioRxiv preprint doi: https://doi.org/10.1101/2021.05.11.443660; this version posted May 11, 2021. The copyright holder for this preprint (which

was not certified by peer review) is the author/funder, who has granted bioRxiv a license to display the preprint in perpetuity. It is made available under aCC-BY-NC-ND 4.0 International license.

Hersch et al.

Engineering the T6SS

fusions from $A$. dhakensis with catalytically inactivated antibacterial effectors (3eff ${ }_{c}$ ) or $\Delta t s s M(\Delta)$. DL, detection limit. One-way ANOVA with Dunnett's multiple comparison test comparing each sample to the $\Delta t s s M$ donor. ${ }^{* *}, \mathrm{p}<0.01 ;{ }^{* * *}, \mathrm{p}<0.001 ; \mathrm{ns}$, not significant. B. As for A. but showing total recipients recovered (Kan ${ }^{R}$ C.F.U.). One-way ANOVA analysis indicates no significant differences. C. Recovery of $A$.

697 dhakensis $\mathrm{CmR}$ colony forming units (total donor cell recovery) with indicated Cre fusions after 698 incubation with $V$. cholerae FIGR recipients. One-way ANOVA with Dunnett's multiple comparison test comparing each sample to the $\Delta t s s M$ donor. ${ }^{* *}, \mathrm{p}<0.01 ; \mathrm{ns}$, not significant.

\section{Supplemental Figure S7: Cre delivery to V. cholerae recipients with chromosomal FIGR. A.}

702 Recombination efficiency of $V$.cholerae recipients with chromosomal FIGR cassette after delivery from $V$.

703 cholerae $4 \operatorname{eff}_{\mathrm{C}}(+)$ or $\Delta \operatorname{tss} M(\Delta)$ strains. B. Recombination efficiency of $V$.cholerae recipients with

704 chromosomal FIGR cassette after delivery from $A$. dhakensis $3 \operatorname{eff}_{\mathrm{C}}(+) \operatorname{or} \Delta \operatorname{tss} M(\Delta)$ strains. DL, 705 approximate detection limit. For each experiment, one-way ANOVAs with Dunnett's multiple 706 comparison tests comparing samples to $\Delta$ tss $M$ donors. ${ }^{*}, \mathrm{p}<0.05$; ns, not significant. 
bioRxiv preprint doi: https://doi.org/10.1101/2021.05.11.443660; this version posted May 11, 2021. The copyright holder for this preprint (which was not certified by peer review) is the author/funder, who ghas granted bioRxiv a license to display the preprint in perpetuity. It is made

A. available under aCC-BY-N
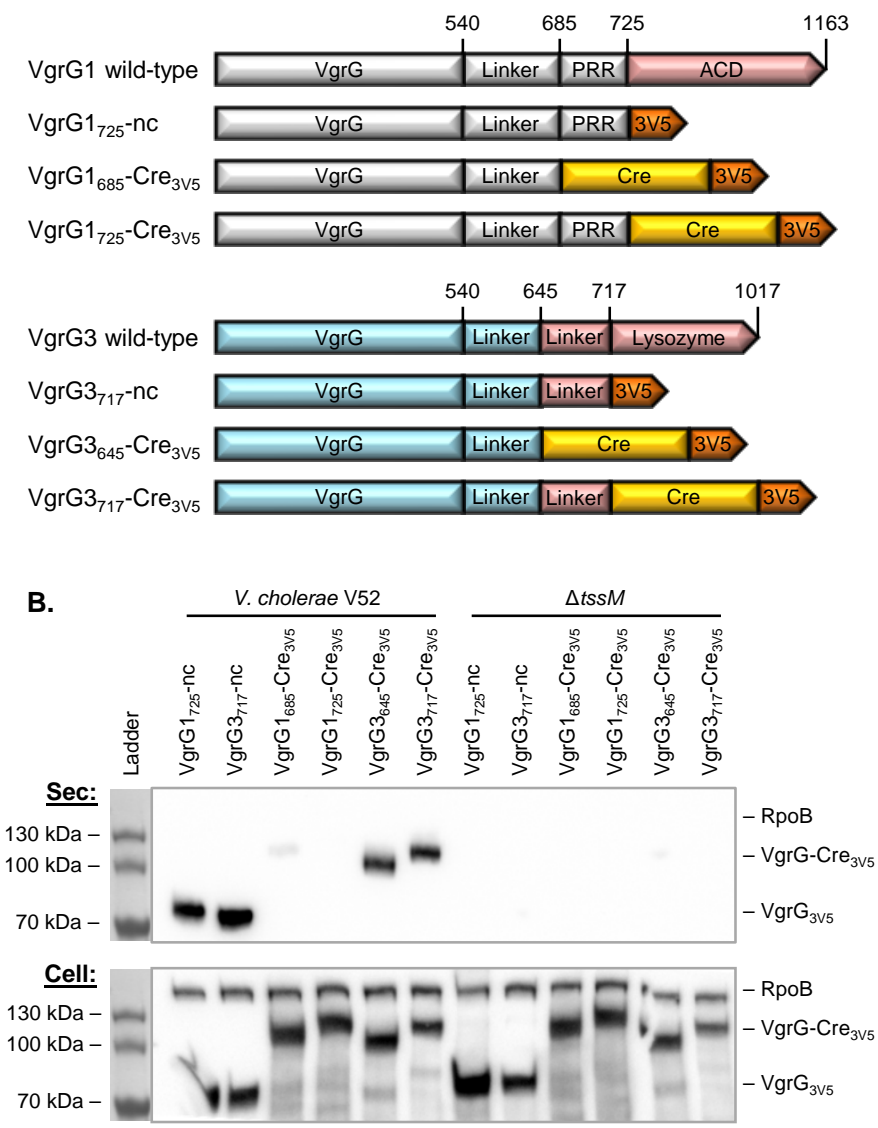

C. $\quad$ Floxed Interruption in Gentamicin Resistance (FIGR)

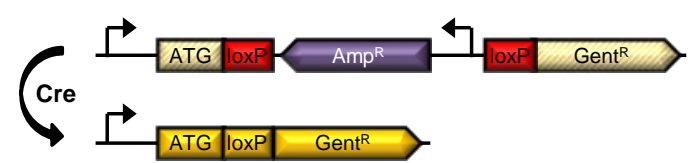

D.

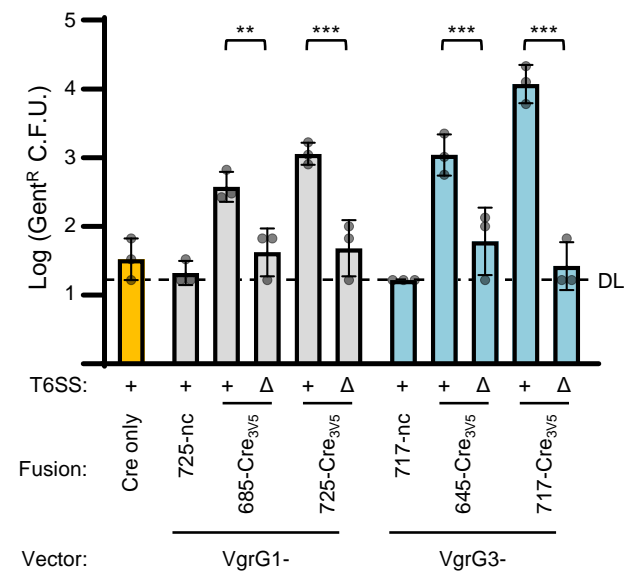

Figure 1: Active VgrG-Cre fusions are secreted and delivered to recipient cells in a T6SS-dependent manner. A. Depiction (not to scale) showing fusions of Cre recombinase (yellow) and 3x V5 tag (orange) to VgrG1 and VgrG3 of V. cholerae V52. VgrG1 (grey) wild-type includes a proline-rich region (PRR) and an actin cross-linking domain (red; ACD). VgrG3 (blue) wild-type includes a lysozyme domain (red) with a linker region leading up to the peptidoglycan binding domain beginning at codon 718. nc, 'no Cre'. B. Western blot showing secretion of VgrG1 and VgrG3 fusions from wild-type $V$. cholerae V52 but not an equivalent tssM mutant. 'Sec' (top) shows secreted fractions, 'Cell' (bottom) shows cell pellet lysates. In addition to $\alpha$-V5, $\alpha$-RpoB antibody was included as a cytoplasm control. Representative of three independent replicates. C. Depiction of the 'Floxed Interruption in Gentamicin Resistance' (FIGR) cassette. An ampicillin resistance cassette (purple) - encoded in the reverse direction and flanked by loxP sites (red) - interrupts the open reading frame of a gentamicin resistance gene (yellow striped). Exposure to Cre removes the block and allows expression of the gentamicin resistance gene (yellow). Promoters are shown as $90^{\circ}$ arrows. Figure is not to scale. ATG, Gent ${ }^{R}$ start codon. D. Recovery of $V$. cholerae Gent ${ }^{R}$ colony forming units (indicative of Cre-mediated FIGR cassette recombination) after delivery from wild-type $(+)$ or $\Delta t s s M(\Delta) \mathrm{V}$. cholerae with indicated Cre fusions to VgrG vectors. DL, detection limit. One-way ANOVA with Sidak's multiple comparison test comparing wild-type and $\Delta t s s M$ donors with equivalent delivery fusions. Recovery from $\Delta t s s M$ samples were not significantly above 'Cre only' or 'no Cre (nc)' controls. **, $p<0.01 ;{ }^{* *}, p<0.001$. 
bioRxiv preprint doi: https://doi.org/10.1101/2021.05.11.443660; this version posted May 11, 2021. The copyright holder for this preprint (which was not certified by peer review) is the author/funder, who has granted bioRxiv a license to display the preprint in perpetuity. It is made available under aCC-BY-NC-ND 4.0 International license.

A.

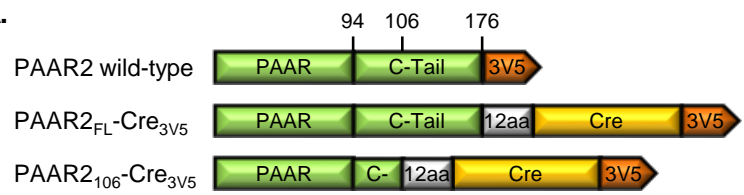

B.

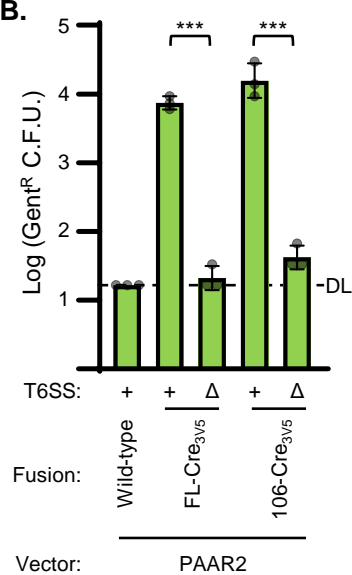

C.

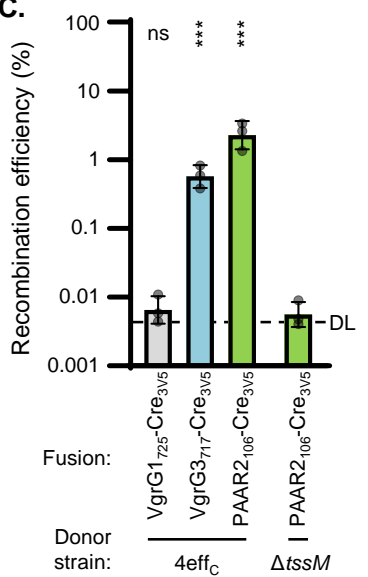

D.

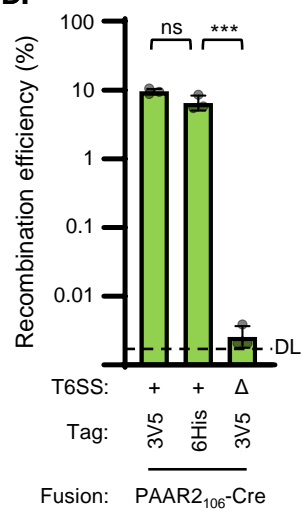

E.

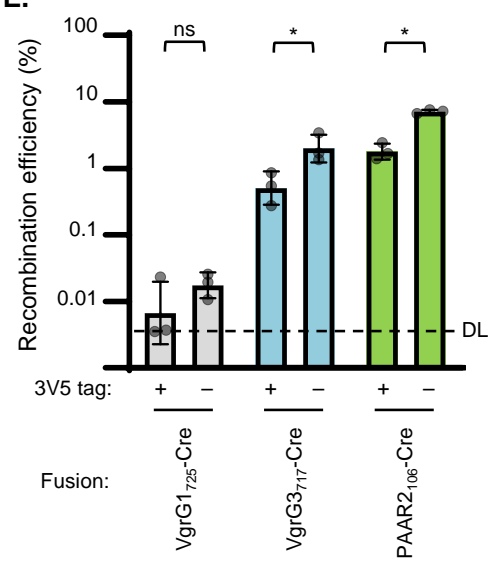

Figure 2: Improving Cre delivery using PAAR2 fusions, an effectorless donor strain, and removing 3 V5 tags. A. Depiction (not to scale) showing fusions of Cre recombinase (yellow) and $3 \times$ V5 tag (orange) to PAAR2 (green) of V. cholerae V52. Fusions include the full-length C-terminal tail (C-Tail) of PAAR2 (FL) or just 12 amino acids of it (C-); 12 amino acids (12aa) are also leftover from the VgrG $_{725}$-Cre (v) $_{5}$ construct (codons $\left.714-725\right)$ used as template for PAAR2 insertion. B. Recovery of Cre-recombined recipient bacteria (Gent ${ }^{R}$ C.F.U.) after delivery from wild-type $(+)$ or $\Delta t s s M(\Delta) V$. cholerae with indicated Cre fusions to PAAR2 vectors. DL, detection limit. One-way ANOVA with Sidak's multiple comparison test: Recovery from $\triangle t s s M$ samples were not significantly above no-Cre (PAAR2 wild-type) control. ${ }^{* *}, p<0.001$. C. Cre fusion delivery from $V$. cholerae with catalytically inactivated antibacterial effectors $\left(4 \mathrm{eff}_{\mathrm{C}}\right.$ ) or $\Delta t S S M(\Delta)$. Data shows recombination efficiency (Gent ${ }^{\mathrm{R}} / \mathrm{Kan}^{\mathrm{R}} \mathrm{C}$.F.U. recovered; recombined / total recipients) as a percentage. DL, approximate detection limit. One-way ANOVA with Dunnett's multiple comparison test comparing each sample to the $\Delta t s s M$ donor strain. $* * \star$, $p<0.001 ;$ ns, not significant. D. Recombination efficiency after delivery from 4 $\operatorname{eff}_{C}(+)$ or $\Delta \operatorname{tsSM}(\Delta) V$. cholerae encoding PAAR ${ }_{106}-$ Cre with either a $3 V 5$ or 6 His tag. DL, approximate detection limit. One-way ANOVA with Tukey's multiple comparison test. ${ }^{* \star}, \mathrm{p}<0.001 ; \mathrm{ns}$, not significant. E. Recombination efficiency after delivery from 4 eff ${ }_{C}$ strain encoding indicated Cre fusions with the $3 \mathrm{~V} 5$ tag present $(+)$ or removed $(-)$. DL, approximate detection limit. One-way ANOVA with Sidak's multiple comparison test comparing samples with and without $3 \mathrm{~V} 5$ tags. ${ }^{*}, \mathrm{p}<0.05$; ns, not significant. 
bioRxiv preprint doi: https://doi.org/10.1101/2021.05.11.443660; this version posted May 11, 2021. The copyright holder for this preprint (which

was not certified by peer review) is the author/funder, who has granted bioRxiv a license to display the preprint in perpetuity. It is made available under aCC-BY-NC-ND 4.0 International license.

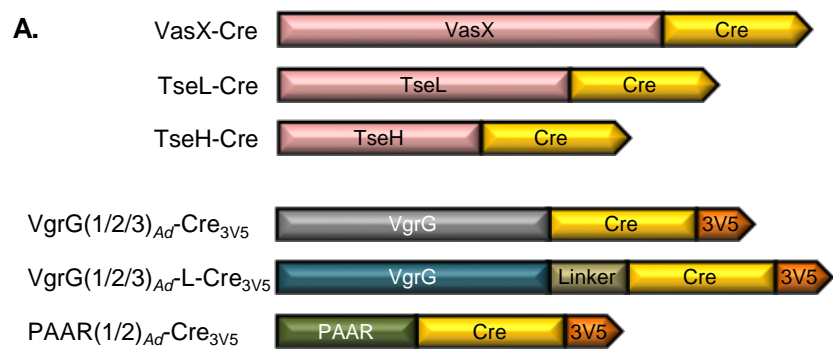

B.

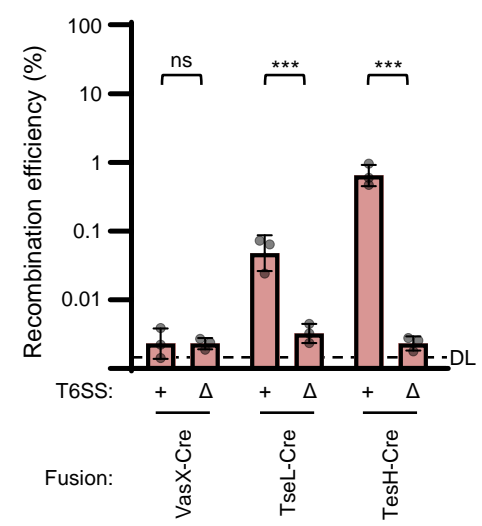

C.

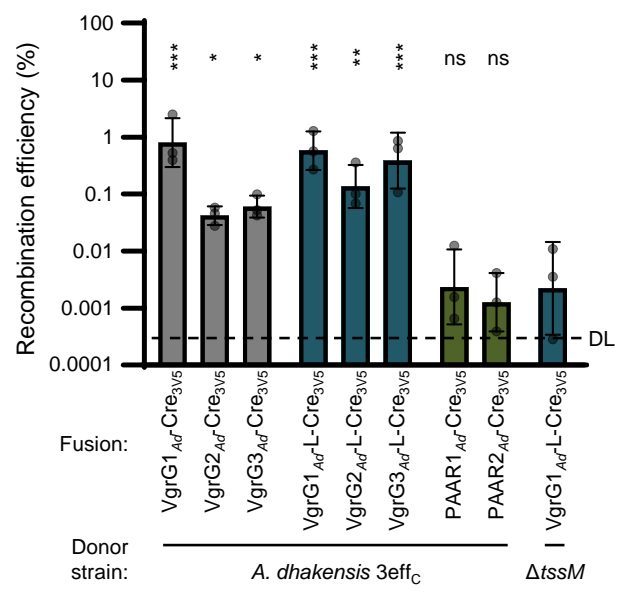

Figure 3: Active Cre can be delivered as effector fusions and by A. dhakensis. A. Depiction (not to scale) showing fusions of Cre recombinase (yellow) and $3 \times \mathrm{V} 5$ tag (orange) to $V$. cholerae T6SS effectors (red) or to $A$. dhakensis PAAR proteins (dark green) and VgrG proteins with (dark blue) or without (dark grey) a flexible linker inserted. B. Recombination efficiency after delivery from $V$. cholerae 4 eff $_{C}$ $(+)$ or $\Delta t S S M(\Delta)$ strains encoding Cre fusions to indicated effector proteins. DL, approximate detection limit. One-way ANOVA with Sidak's multiple comparison test comparing $4 \mathrm{eff}_{\mathrm{C}}$ and $\Delta t s s M$ donors with equivalent delivery fusions. ${ }^{* \star}, \mathrm{p}<0.001$; ns, not significant. C. Recombination efficiency after delivery of Cre fusions from $A$. dhakensis with catalytically inactivated antibacterial effectors (3eff ${ }_{C}$ ) or $\Delta \operatorname{tss}(\Delta)$. DL, approximate detection limit. One-way ANOVA with Dunnett's multiple comparison test comparing each sample to the $\Delta t s s M$ donor. ${ }^{*}, p<0.05 ;{ }^{\star *}, p<0.01 ;{ }^{* \star *}, p<0.001 ;$ ns, not significant. 
bioRxiv preprint doi: https://doi.org/10.1101/2021.05.11.443660; this version posted May 11, 2021. The copyright holder for this preprint (which was not certified by peer review) is the author/funder, who has granted bioRxiv a license to display the preprint in perpetuity. It is made available under aCC-BY-NC-ND 4.0 International license.

A.

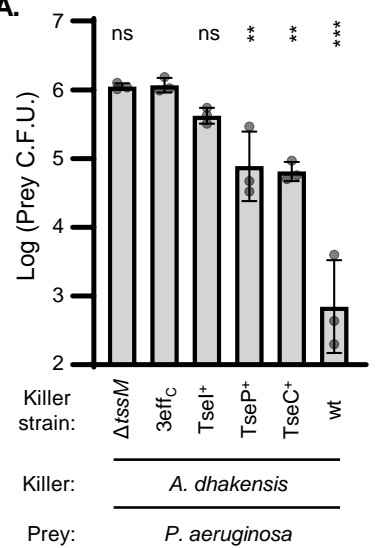

B.

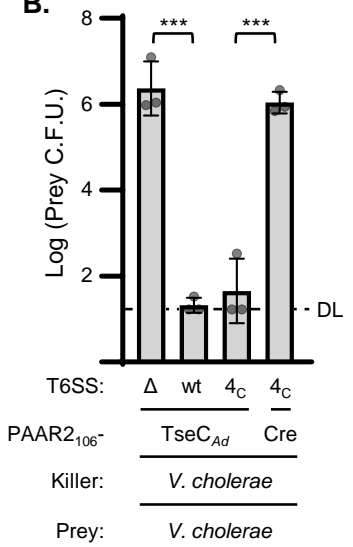

C.

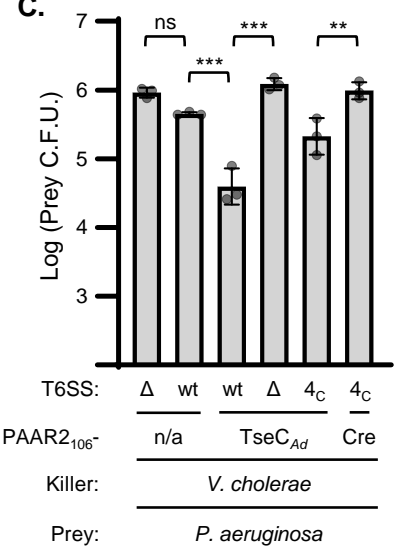

Figure 4: Fusion of PAAR2 ${ }_{106}$ to the $\boldsymbol{A}$. dhakensis effector, TseC, empowers $\boldsymbol{V}$. cholerae to kill $\boldsymbol{P}$. aeruginosa. A. Prey $P$. aeruginosa recovery after incubation with $A$. dhakensis killer cells. Prey $P$. aeruginosa has $\Delta h s i B(\Delta t s s B)$ mutations in all three T6SS. Killer strains have T6SS-null mutation $(\Delta t s s M)$ or a wild-type T6SS with all effectors intact (wt), all antibacterial effectors catalytically inactivated (3eff $\mathrm{C}_{\mathrm{C}}$ ), or a single active effector (indicated) while the other effectors are inactivated. One-way ANOVA with Dunnett's multiple comparison test comparing all samples to the 3 eff $_{C}$ killer strain. ${ }^{* *}$, $p<0.01$; ${ }^{* \star *}$, $\mathrm{p}<0.001$; ns, not significant. B. Prey $V$. cholerae $(\Delta t s s M)$ recovery after incubation with $V$. cholerae killer cells encoding PAAR2 ${ }_{106}$ fusions to $A$. dhakensis TseC $\left(T_{s e C}{ }_{A d}\right)$ or Cre as a control. Killer strains have $\Delta t S S M(\Delta)$ or a wild-type T6SS with all effectors intact (wt) or all native antibacterial effectors catalytically inactivated $\left(4 \mathrm{eff}_{\mathrm{C}}\right)$. DL, detection limit. One-way ANOVA with Sidak's multiple comparison test. $* \star \star, p<0.001 ; \mathrm{ns}$, not significant. C. Prey $P$. aeruginosa ( $\Delta$ hsiB mutations in all three T6SS) recovery after incubation with $V$. cholerae killer cells with no fusion construct (n/a) or encoding PAAR2 ${ }_{106}$ fusions to $A$. dhakensis TseC $\left(\operatorname{TseC}_{A d}\right)$ or Cre as a control. Killer strains have $\Delta t s s M(\Delta)$ or a wild-type T6SS with all effectors intact (wt) or all native antibacterial effectors catalytically inactivated $\left(4 \mathrm{eff}_{C}\right)$. One-way ANOVA with Sidak's multiple comparison test. ${ }^{* \star}, \mathrm{p}<0.01 ;{ }^{* \star \star}, \mathrm{p}<0.001 ;$ ns, not significant. 
bioRxiv preprint doi: https://doi.org/10.1101/2021.05.11.443660; this version posted May 11, 2021. The copyright holder for this preprint (which was not certified by peer review) is the author/funder, who has granted bioRxiv a license to display the preprint in perpetuity. It is made available under aCC-BY-NC-ND 4.0 International license.

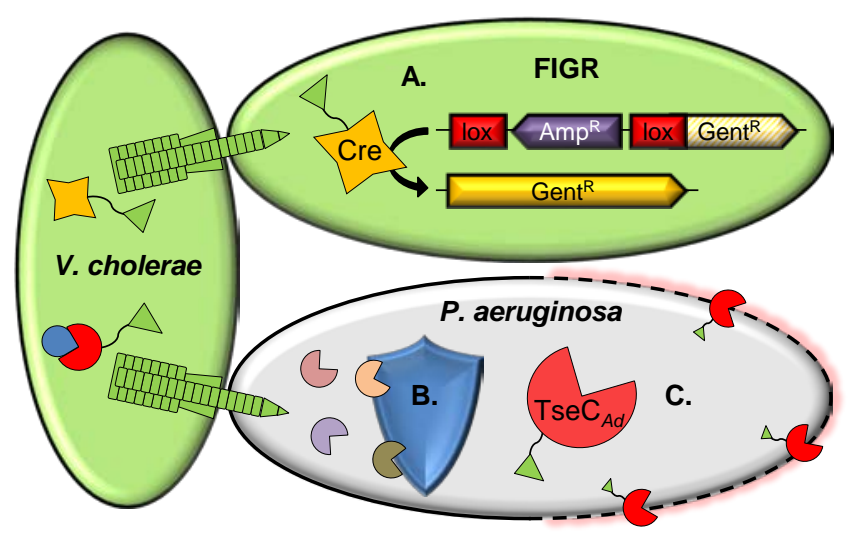

Figure 5: Model of engineered T6SS-mediated delivery of Cre recombinase and $\mathrm{TseC}_{A d}$. A. Engineered T6SSs of $V$. cholerae or $A$. dhakensis donor cells deliver active Cre recombinase at the protein level. Delivered Cre instigates recombination of the floxed interruption in gentamicin resistance (FIGR) cassette in recipient cells. B. $P$. aeruginosa exhibits natural resistance (by unknown mechanisms) to all four antibacterial effectors of wild-type $V$. cholerae. C. $V$. cholerae engineered to deliver the $A$. dhakensis effector, $\operatorname{TseC}_{A d}$, gains the ability to kill $P$. aeruginosa. 
bioRxiv preprint doi: https://doi.org/10.1101/2021.05.11.443660; this version posted May 11, 2021. The copyright holder for this preprint (which

was not certified by peer review) is the author/funder, who has granted bioRxiv a license to display the preprint in perpetuity. It is made available under aCC-BY-NC-ND 4.0 International license.

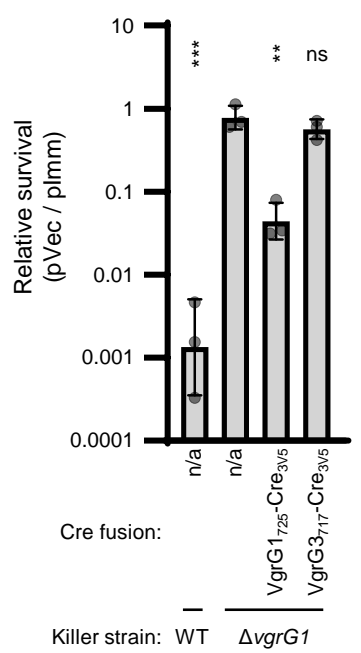

Supplemental Figure S1: The VgrG $1_{725}-\mathrm{Cre}_{3 \mathrm{~V} 5}$ fusion can deliver TseL to kill sensitive prey. T6SS competition assay showing killing by wild-type V52

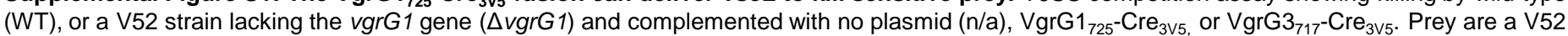
strain lacking the TseL immunity gene, tsiV1, and complemented with either empty vector (pVec) or tsiV1 on a plasmid (plmm). Survival of the prey is shown as a ratio of recovered C.F.U. (pVec/ plmm). One-way ANOVA with Dunnett's multiple comparison test comparing each killer strain to $\Delta v g r G 1$ with no plasmid. ${ }^{\star *}, p<0.01 ;{ }^{* \star *}, p<0.001 ;$ ns, not significant. 
bioRxiv preprint doi: https://doi.org/10.1101/2021.05.11.443660; this version posted May 11, 2021. The copyright holder for this preprint (which was not certified by peer review) is the author/funder, who has granted bioRxiv a license to display the preprint in perpetuity. It is made available under aCC-BY-NC-ND 4.0 International license.

A.

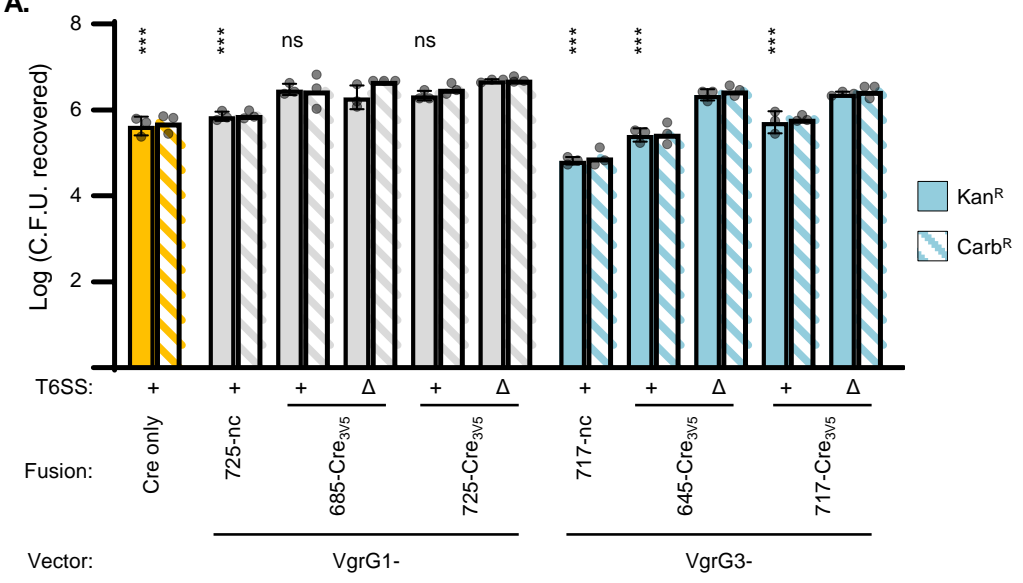

B.

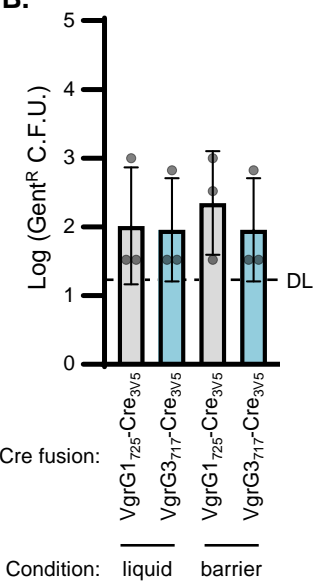

C.

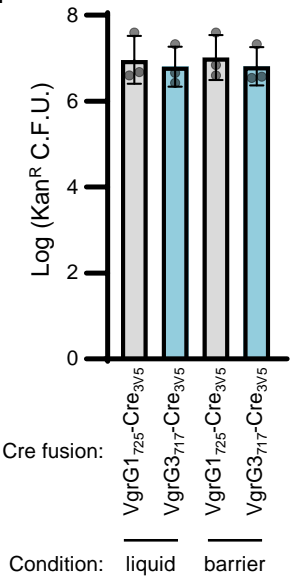

D.

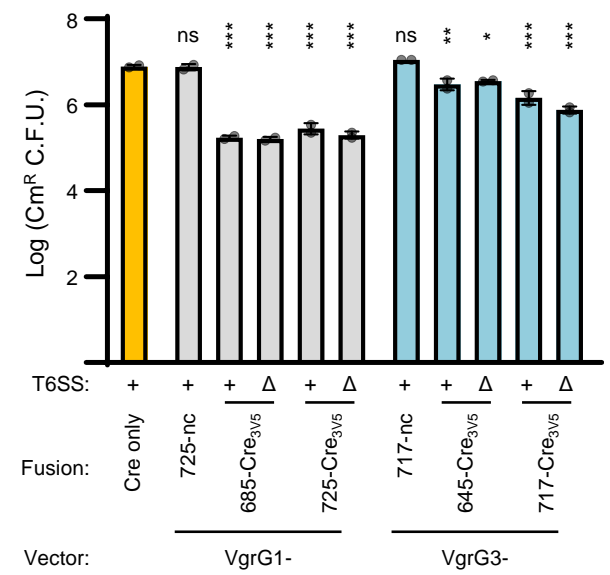

Supplemental Figure S2: VgrG fusions total donor and recipient survival, liquid or barrier controls, related to Figure 1D.

A. Recovery of $V$. cholerae $\mathrm{Kan}^{\mathrm{R}}$ (total recipients) or $\mathrm{Carb}^{\mathrm{R}}$ (recipients with at least one non-recombined copy of FIGR) colony forming units after delivery from wild-type (+) or $\Delta \operatorname{tss} M(\Delta)$ V. cholerae with indicated Cre fusions to VgrG vectors. One-way ANOVA with Sidak's multiple comparison test comparing wild-type and $\Delta t s s M$ donors with comparable delivery fusions. $\mathrm{Kan}^{\mathrm{R}}$ statistics are shown, similar results were obtained for Carb ${ }^{\mathrm{R}}$. No significant differences comparing $\mathrm{Kan}^{\mathrm{R}}$ and $\mathrm{Carb}^{\mathrm{R}}$ results for any delivery fusion strains. ${ }^{\star \star \star}, \mathrm{p}<0.001$; ns, not significant. B, C. Cre delivery in liquid suspension (liquid) or when donor and recipient were separated by a nitrocellulose membrane (barrier). Recovery of $V$. cholerae colony forming units after incubating with wild-type $V$. cholerae with indicated Cre fusions. One-way ANOVA analyses indicate no significant differences. B. Gent ${ }^{R}$ C.F.U. indicative of Cre-mediated FIGR cassette recombination. DL, detection limit. C. Total recipient C.F.U. $\left(K_{a n}^{R}\right)$. D. Recovery of $V$. cholerae $\mathrm{Cm}^{\mathrm{R}}$ colony forming units (total donor cell recovery) with indicated Cre fusions to VgrG vectors after incubation with $V$. cholerae FIGR recipients. One-way ANOVA with Dunnett's multiple comparison test comparing each strain to the 'Cre only' strain. *, $p<0.05$; ${ }^{\star *}, p<0.01$; ${ }^{\star * \star}, p<0.001$; ns, not significant. 
bioRxiv preprint doi: https://doi.org/10.1101/2021.05.11.443660; this version posted May 11, 2021. The copyright holder for this preprint (which

was not certified by peer review) is the author/funder, who has granted bioRxiv a license to display the preprint in perpetuity. It is made available under aCC-BY-NC-ND 4.0 International license.

A.

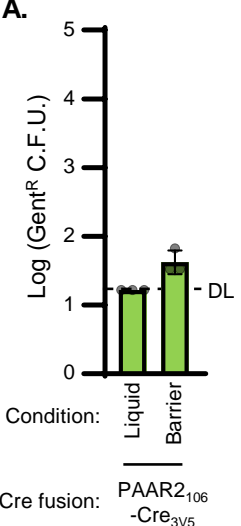

B.

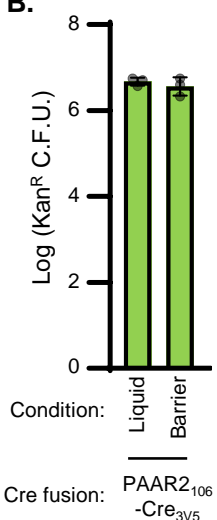

C.

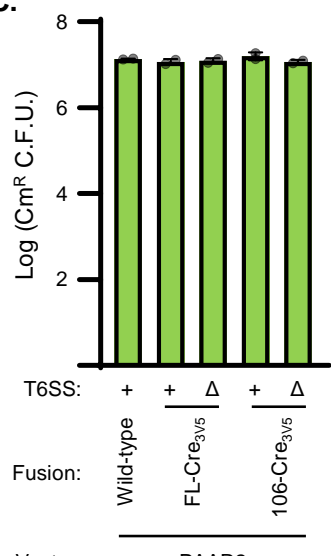

D.

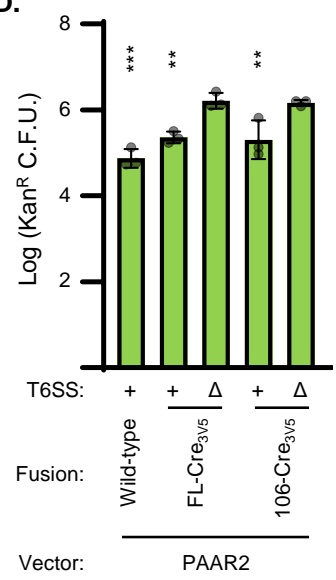

Supplemental Figure S3: PAAR2 fusions total donor and recipient survival, liquid or barrier controls, related to Figure 2B. A, B. Cre delivery in liquid suspension (liquid) or when donor and recipient were separated by a nitrocellulose membrane (barrier). Recovery of recipient colony forming units after incubating with wild-type V. cholerae with PAAR2 ${ }_{106}-\mathrm{Cre}_{3 V 5}$. A. Gent ${ }^{R}$ C.F.U. indicative of Cre-mediated FIGR cassette recombination. DL, detection limit. B. Total recipient C.F.U. $\left(K^{R}{ }^{R}\right)$. C. Recovery of $V$. cholerae $\mathrm{Cm}^{\mathrm{R}}$ colony forming units (total donor cell recovery) with indicated Cre fusions to PAAR2 after incubation with $V$. cholerae FIGR recipients. One-way ANOVA analysis indicates no significant differences. D. Recovery of $V$. cholerae $\operatorname{Kan}^{R}$ (total recipients) colony forming units after delivery from active T6SS (+) or $\Delta t s s M(\Delta)$ $V$. cholerae with indicated Cre fusions to PAAR2 vectors. One-way ANOVA with Sidak's multiple comparison test comparing active T6SS and $\Delta t s s M$ donors with comparable delivery fusions. ${ }^{* *}, p<0.01 ;{ }^{* *}, p<0.001$. 
bioRxiv preprint doi: https://doi.org/10.1101/2021.05.11.443660; this version posted May 11, 2021. The copyright holder for this preprint (which

was not certified by peer review) is the author/funder, who has granted bioRxiv a license to display the preprint in perpetuity. It is made available under aCC-BY-NC-ND 4.0 International license.

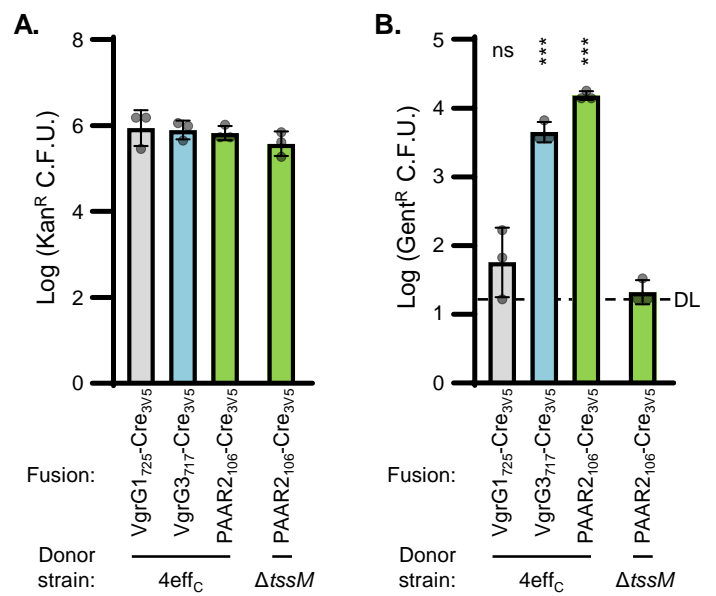

Supplemental Figure S4: Cre fusion delivery from effectorless donor strain, related to Figure 2C. A. Total recipients recovered (Kan ${ }^{R}$ C.F.U.) after delivery from $V$. cholerae with catalytically inactivated antibacterial effectors (4eff ${ }_{C}$ ) or $\Delta t s s M(\Delta)$. One-way ANOVA with Dunnett's multiple comparison test comparing each sample to the $\Delta t s s M$ donor strain. ${ }^{* \star}, p<0.001$; ns, not significant. B. As for $\mathbf{A}$. but showing Crerecombined recipient bacteria (Gent ${ }^{R}$ C.F.U). DL, detection limit. One-way ANOVA analysis indicates no significant differences. 
bioRxiv preprint doi: https://doi.org/10.1101/2021.05.11.443660; this version posted May 11, 2021. The copyright holder for this preprint (which

was not certified by peer review) is the author/funder, who has granted bioRxiv a license to display the preprint in perpetuity. It is made available under aCC-BY-NC-ND 4.0 International license.

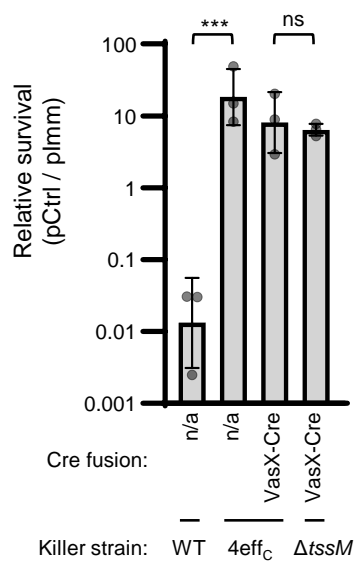

Supplemental Figure S5: The VasX-Cre fusion does not kill sensitive prey. T6SS competition assay showing killing by V52 wild-type (WT), catalytically inactivated antibacterial effectors $\left(4 \mathrm{eff}_{C}\right)$, or inactivated T6SS $(\Delta t S S M)$. Strains were complemented with no plasmid (n/a), or VasX-Cre. Prey are a V52 strain lacking the VasX immunity gene, tsiV2, and complemented with either tsiV2 (plmm) or a non-protective chaperone gene as a control (VCA0019; pCtrl). Survival of the prey is shown as a ratio of recovered C.F.U. (pCtrl / plmm). One-way ANOVA with Sidak's multiple comparison test comparing no plasmid WT or VasX-Cre delivery to controls. $* \star \star, p<0.001$; ns, not significant. 
bioRxiv preprint doi: https://doi.org/10.1101/2021.05.11.443660; this version posted May 11, 2021. The copyright holder for this preprint (which was not certified by peer review) is the author/funder, who has granted bioRxiv a license to display the preprint in perpetuity. It is made available under aCC-BY-NC-ND 4.0 International license.
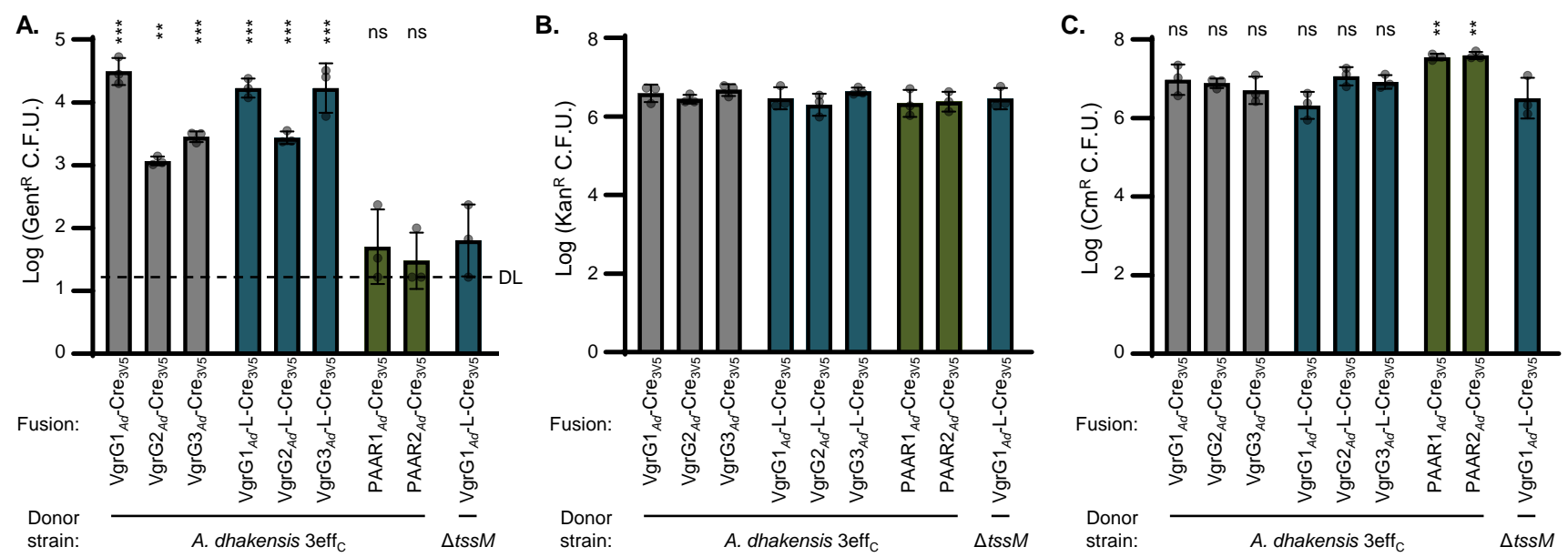

Supplemental Figure S6: A. dhakensis donor total recipient survival and recombinant recovery, related to Figure $3 \mathrm{C}$. A. Recovery of Cre-recombined recipient bacteria (Gent ${ }^{R}$ C.F.U.) after delivery of Cre fusions from $A$. dhakensis with catalytically inactivated antibacterial effectors (3eff $\mathrm{C}_{\mathrm{C}}$ ) or $\Delta t S S M(\Delta)$. DL, detection limit. One-way ANOVA with Dunnett's multiple comparison test comparing each sample to the $\Delta t s s M$ donor. ${ }^{\star \star}, p<0.01 ;{ }^{\star \star \star}, p<0.001 ;$ ns, not significant. B. As for A. but showing total recipients recovered (Kan ${ }^{R}$ C.F.U.). One-way ANOVA analysis indicates no significant differences. C. Recovery of $A$. dhakensis $\mathrm{CmR}$ colony forming units (total donor cell recovery) with indicated Cre fusions after incubation with $V$. cholerae FIGR recipients. One-way ANOVA with Dunnett's multiple comparison test comparing each sample to the $\Delta t s s M$ donor. ${ }^{* *}, \mathrm{p}<0.01 ;$ ns, not significant. 
bioRxiv preprint doi: https://doi.org/10.1101/2021.05.11.443660; this version posted May 11, 2021. The copyright holder for this preprint (which

was not certified by peer review) is the author/funder, who has granted bioRxiv a license to display the preprint in perpetuity. It is made available under aCC-BY-NC-ND 4.0 International license.

A.

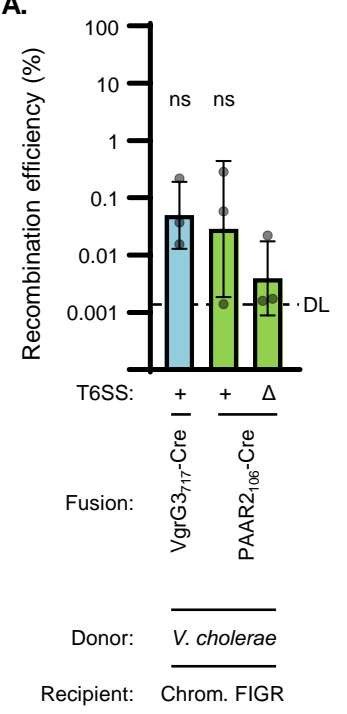

B.

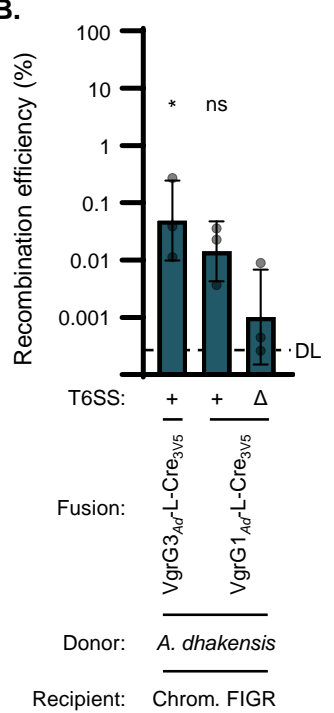

Supplemental Figure S7: Cre delivery to $V$. cholerae recipients with chromosomal FIGR. A. Recombination efficiency of $V$.cholerae recipients with chromosomal FIGR cassette after delivery from $V$. cholerae $4 \mathrm{eff}_{C}(+)$ or $\Delta t s s M(\Delta)$ strains. B. Recombination efficiency of $V$.cholerae recipients with chromosomal FIGR cassette after delivery from $A$. dhakensis 3eff $_{\mathrm{C}}(+)$ or $\Delta t s s M(\Delta)$ strains. DL, approximate detection limit. For each experiment, one-way ANOVAs with Dunnett's multiple comparison tests comparing samples to $\Delta t s s M$ donors. * $\mathrm{p}<0.05$; ns, not significant. 